\title{
İnsan Kaynakları Yönetimi Uygulamalarının Çalışanların İş Tatminine, Yenilikçiliğine ve Performansına Etkisi
}

\section{Human Resources Management Applications The Effect of Employees on Job Satisfaction, Innovation and Individual Performance}

\author{
İsa İSPİR, Kahramanmaraş Sütçü İmam Üniversitesi, Türkiye, isaispir_@hotmail.com \\ Orcid No: 0000-0003-3825-7015 \\ Salih YEŞİL, Kahramanmaraş Sütçü İmam Üniversitesi, Türkiye, syes66@hotmail.com \\ Orcid No: 0000-0003-3237-2258
}

\begin{abstract}
Öz: Bu çalışmanın amacı, insan kaynakları yönetimi uygulamalarında; eğitim, performans değerlendirme, ödüllendirme ve personel güçlendirmenin, çalışanların iș tatminine, yenilikçi davranışına ve bireysel performansına etkisi olup olmadiğını tespit etmektir. Bu bağlamda Kahramanmaraş ilinde bulunan bir kamu kurumu çalışanlarından 226 kişiye anket uygulanmıştır. Çalışma sonucunda elde edilen bulgulara göre, insan kaynaklarl yönetimi uygulamalarında eğitim ve personel güçlendirmenin, iș tatmini üzerinde olumlu yönde etkisinin olduğu, personel güçlendirmenin; bireysel performans ve yenilikçi davranış üzerinde olumlu yönde etkisinin olduğu belirlenmiştir.
\end{abstract}

Anahtar Sözcükler: Insan Kaynakları Yönetimi Uygulamaları, İş Tatmini, Yenilikçi Davranış, Bireysel Performans JEL Siniflandirmast: M10, M12, M53, M54

Absrect: The aim of this study is to implement human resources management; training, performance evaluation, rewarding and staff empowerment, to determine whether training, performance evaluation, rewarding and staff empowerment have an impact on employee satisfaction, innovative behavior and individual performance. In this context, a questionnaire was applied to 226 people in a public institution in Kahramanmaraş. According to the findings of the study, it is observed that training and personnel empowerment from human resources management practices have a positive effect on job satisfaction, staff empowerment; It has been determined that it has a positive effect on individual performance and innovative behavior.

Keywords: Human Resources Management Practices, Job Satisfaction, Innovative Behaviour, Individual Performance. JEL Classification: M10, M12, M53, M54

\section{Giriș}

İnsan kaynakları yönetimi uygulamaları, günümüzün getirmiş olduğu şartlarda hiç şüphesiz önemle ele alınmaktadır. İnsan eskiden, diğer üretim faktörleri gibi değerlendirilirken, artık günümüzde üretim ve hizmetin elde edilmesi sürecinde çok önemli hale gelmiştir. Bunun sebebi ise dünyada çok hızlı bir değişimin yaşanmasıdır. Bilim ve teknolojinin her alanında yaşanan yenilikler kurumları yoğun bir rekabet ortamına taşımaktadır. Bu yoğun rekabet içerisinde birçok kurum yaşamını sürdürmek, iyi bir üretim ve hizmet sunup, verimliliklerini artırabilmek için daha etkili yönetilmeleri gerekliliği konusunda bilinçlenmişlerdir. Rekabet sürecinde, kaliteli üretim ve hizmetin gerektirdiği temel unsur ise iyi eğitilmiş, örgütle özdeşleşmiş, kendisini sürekli geliştirilen, yeniliklere açık, katılımcı, yapıcı fikirler ortaya sunan, yaratıcı olan sürekli bir iş gücüdür. Yani sıralanan tüm bu unsurların bir sonucu olan rekabetin temel unsuru insan öğesidir. Bunun için örgütlerde insan gücünün en etkili ve verimli bir şekilde kullanılması gerekmektedir. Kurumlar, çok değişken ve karmaşık olan insan davranışlarını anlama, yorumlama ve geliştirme çabaları sonucunda insan kaynakları yönetimine odaklanmış ve akademik çalışmaların önemli bir çalışma alanını oluşturmuştur.

Günümüzde kamu ve özel sektör alanında yer alan kuruluşlar, bilim, teknoloji, iletişim ve tüm alanlarda olduğu gibi hızlı bir değişim sürecine girmişlerdir. Bu süreçte ise başarılı olmaları, sahip oldukları insan kaynağının niteliğine bağlıdır. Gerek kamu kurumlarında olsun gerekse de özel kuruluşlarda, örgütlerin kaliteli üretim ve hizmet sunup, rekabet avantajı sağlayabilmeleri insan odaklı yönetim tarzlarını benimsemekle mümkün olmaktadır. Çalışanlarına değer veren, çalışanların bireysel gelişim ihtiyaçlarını karşılayan, performanslarını eşit ve adalete uygun bir şekilde bilimsel yöntemlerle değerlendiren, çalışanlarını ödüllendiren, çalışanlarının yaptıkları görevlerle ilgili öncelik almalarını sağlayıp onları güçlendiren, çalışanların yenilikçiliklerini destekleyen, iş tatminlerini artıran ve beklentilerine yanıt veren kuruluşların rekabet avantajı sağladıkları görülmektedir. Bu nedenle insan kaynaklarını etkili ve verimli bir şekilde kullanan kuruluşların, bunu kullanamayan kuruluşlara göre gelecekte daha başarılı olacakları kaçınılmazdır.

Literatür incelendiğinde, insan kaynakları yönetimi uygulamaları konusunda gerek kamu gerekse de özel sektörde çok sayıda çalışmanın yapıldığı görülmektedir. (Pekdemir, vd., 2014;Yumuşak, 2008; Yetiş ve Katlav, 2017;Yiğit 2010; Yılmaz 2009; Akçakanat 2009; Bektaş ve Karagöz 2018; Çavuş 2006). Özellikle özel sektörde, insan kaynakları yönetimi uygulamalarıyla ilgilipersonel seçme (Haznedar, 2006), iş tatmini (Garcia 2005; Yiğit 2010; Hackman ve 
Oldham 1975), eğitim (Yılmaz 2009; Yiğit, 2010), yenilikçilik (Peçen, 2012; Eryiğit, 2013), çalışan performansı (Altındağ ve Akgün 2015; Tompkins 1995), performans değerlendirme (Erdoğmuş ve Şeneldir, 2009; Eren, 2006), kurumsal performans (Yıldırım, 2015), yenilikçi davranış (Akgül, 2018; Sözbilir 2018) gibi, birçok konu üzerindeki ilişkileri ve etkileri incelenmiştir. Literatür incelendiğinde, konuyla ilgili çalışmaların özel sektörde yoğunlaştığ1 görülmektedir. Kamu alanında yapılan çalışmaların ise özel sektöre göre daha sınırlı sayıda çalışmaların yapıldığını, ilgili literatürde görülmektedir. Genel olarak değerlendirildiğinde ilgili literatürde insan kaynakları yönetimi uygulamaları konusu, farklı yönleriyle araştırılmış ve araştırılmaya devam etmektedir. Bu çalışmada, bu yönde bir özellik göstermekte ve özellikle kamu alanında yapılan çalışmaların sınırlı oluşundan yola çıkarak, insan kaynakları yönetimi uygulamalarından; eğitim, performans değerlendirme, ödüllendirme ve personel güçlendirme ile iş tatmini, yenilikçi davranış ve bireysel performans konularını incelemektir. Ayrıca, daha önceki çalışmalardan farklı olarak çalışmaya bir takım yeni konular eklenmiş ve çalışma daha kapsamlı bir bakış açısıyla değerlendirilmiştir. Diğer taraftan, insan kaynakları yönetimi uygulamaları konusunda, Kahramanmaraş’ta kamu alanında yapılmış bir çalışmaya rastlanılmamıştır. Çalışma, bu yönüyle önem arz etmekte ve ilgili yazına önemli katkıda bulunacağı düşünülmektedir.

Çalışmada birinci bölümü oluşturan giriş bölümünden sonra, ikinci bölümde araştırmanın amaçları doğrultusunda hipotezlerin oluşumu ile eğitim, performans değerlendirme, ödüllendirme, personel güçlendirme, iş tatmini, bireysel performans ve yenilikçi davranış konuları açıklanmıştır. Üçüncü bölümde, araştırmanın metodolojisi, dördüncü bölümde, araştırmanın bulgularına, son bölümde de sonuç ve önerilere yer verilmiştir.

\section{Arştırmanın Temel Değişkenleri}

Bu bölümde araştırmanın temel değişkenlerini oluşturan; eğitim, performans değerlendirme, ödüllendirme, personel güçlendirme ile iş tatmini, bireysel performans ve yenilikçi davranış ele alınıp teorik olarak açıklanmıştır.

\section{1. Ĕ̈itim}

Eğitim, kurumda yeni işe alınmış ve mevcut çalışanları işlerini etkili bir şekilde yerine getirmek için ihtiyaç duydukları temel becerileri kazandırma ve öğretme sürecidir. Alternatif olarak söyleyecek olursak; eğitim, çalışanlarının bilgi ve becerilerini arttırmaktır. Bu nedenle eğitim, örgüt üyelerine yardımcı olmalarını sağlamak için yürütülen öğretme ve öğrenme faaliyetlerine atıfta bulunmaktadır; bu bilgiler, yeteneklerini yerine getirmek için gerekli bilgi, beceri ve tutumları edinir ve uygularlar (Khanka, 2007: 107). Bir bireyde: işte geliştirme kabiliyetini arttıracak nispeten bireyde kalıcı bir değişiklik istemekle ilgili bir öğrenme tecrübesidir. Genellikle eğitimin, becerilerin, bilginin, tutumların veya davranışların değişebileceğini söyleriz. Bu çalışanların ne bildiklerini, nasıl çalıştıklarını, çalışmalarına yönelik tutumlarını, değiştirdikleri veya iş arkadaşları veya yöneticileriyle etkileşimleri anlamına gelebilir (De Cenzo ve Robbins, 1996: 237). Kurumlarda eğitim ve geliştirme faaliyetlerinin ulaşacağı nokta, tüm yapılan çalışmalarda çalışanların işini daha iyi yapma çabasıdır. Bu çabanın, bireysel çalışmaların yanında belirli bir arayışı da gerektirdiği doğrudur. Çalışanlar, kurum tarafından sağlanan eğitim firsatlarıyla kendilerini geliştirme firsatları bulmalıdırlar. Böylece eğitim ve geliştirmedeki amaç, personelin kendisini geliştirme kaygısına sahip olmaları ve hayat boyu öğrenme alışkanlığını edinmeleridir (Fındıkçı, 2000: 281).

Günümüz iş dünyasında hayatta kalmak ve örgütün yaşamını sürdürmesi gerçekten güçleşmiştir. Baş döndüren değişimler, artan rekabet ve değişen müşteri beklenti ve gereksinimleri daha yaratıcı, yenilikçi, hızlı ve esnek olmaya zorlamaktadır. Bunu gerçekleştirmenin en önemli unsurlarından biri de çalışanlara daha fazla önem ve değer vermek ve çalışanlardan yararlanmakla mümkün olabilecektir. Kurumda çalışanlara önem ve değer vermenin ve çalışanlardan maksimum düzeyde yararlanmanın yollarından biri de eğitim ve geliştirmedir (Yeşil, 2014: 194-195). İnsan kaynakları yönetimi uygulamalarında eğitim çok önemlidir. İnsanın önemi ve değerinin, çağdaş toplumların vazgeçilmez gerçeği olduğu, bilginin ise temel güç ve sermaye olduğu bilinmektedir. İnsan kaynakları ihtiyaçlarının belirlenmesi, ihtiyaçları karşılama çabaları, iş başvuruları alma, gerekli görüşmelerin yapılması, ilgili testlerin yapılması ve kurumda çalışacak personelin seçilmesi ile başlayan süreç sonrasında nihayet sıra eğitim ve geliştirme faaliyetlerine gelmiş bulunmaktadır (Fındıkçı, 2000: 243). Eğitim, insanların belli bir amaçla bilgi ve beceri kazanmalarını ve mevcut bilgi ve becerilerinin artmasını sağlayan sistemli bir aşamadır. Aynı zamanda eğitim, inanç, tutum ve davranışlarda gelişme sağlayan bir süreçtir. Eğitim ve geliştirmede gerçek amaç, eğitilenlerin davranışlarında bir değişiklik gerçekleştirmek suretiyle çalışanların yeteneklerini şuandaki ve gelecekteki görevlere ilişkin o görevi yapabilecek düzeye yükseltmektir (Bingöl, 2013: 282). Genel olarak bakıldığında eğitim, toplumun yaratıcı gücünü ve etkinliğini yükseltir, kalkınmanın gerçekleştirilebilmesi için gerekli yüksek nitelikte kişilerin yetiştirilmesini sağlayan ve onlara kabiliyetleri yönünde yetişme imkânı veren etkili bir araçtır. Bu bağlamda eğitim kalkınmanın ve gelişmenin motorunu oluşturur (Czinkota, vd., 1998: 518-521, Aktaran, Eren, 2011: 119).

\subsection{Performans Değerlendirme}

Yönetim bilimi açısından "performans” kavramı, önceden belirlenen amaçlara ve standartlara uygun olarak bir faaliyetin yerine getirilmesi ya da iş görenin bir işte gösterdiği başarıyı ifade etmektedir. Başka bir ifadeyle, bir işi yerine getiren bir kişinin, bir toplumun ya da bir kurumun o iş için amaçlanan hedefe yönelik olarak neyi 
sağlayabildiğinin nicel (miktar) ya da nitel (kalite) olarak ifade edilmesidir (Baş ve Atar, 1990: 13). Performans, genel olarak hedeflenen ve planlanan bir faaliyetin sonucunda elde edilenleri niceliksel veya niteliksel olarak belirleyen bir kavram olarak kabul edilir (Akal, 2005: 17). Kamu kurumlarında performans, bir kamu kurumunun başkalarına göre veya kendi geçmişine göre daha etkili ve verimli olmasını kapsamaktadır (Usta, 2010: 34-37).

Performans değerlendirme, bir çalışanın iş performansının niceliksel ve nitel yönlerini değerlendiren süreçtir. Performans değerlendirmeleri, hem çalışanın hem de işverenin bazı temel ve önemli sorunlarına cevaplar sağlamalıdır: Ne kadar iyi olduğum, nasıl iyi yapabilirim, çalışanlarımızın bireysel olarak ve ortak çalışarak ne kadar iyi iş yaptıklarını, çalışanlarımıza yardımcı olabilmek için ne yapabilirim? Bizim için ve çalışanlar için çeşitli personel eylemleri uygun mu? gibi sorulara cevap bulmamıza yardımcı olur (Leap ve Crino, 1993: 332). Performans değerleme, bir çalışanın kurumda görevi ne olursa olsun çalışmalarını, etkinliklerini, eksikliklerini, yeterliliklerini, fazlalıklarını, yetersizliklerini kısacası bir bütün olarak çalışanın performansının gözden geçirilmesidir (Fındıkçı, 2012: 296). Başka bir tanımda ise, performans değerleme, çalışanların yaptığı görevde elde ettikleri başarı, gelişme ve ilerlemenin düzenli olarak ölçülmesidir (Güney, 2014: 183).

İnsan kaynakları yönetiminin en önemli uygulamalarından birisi de insan kaynaklarının değerlenmesidir. Çünkü bu süreç o kadar önemlidir ki, değerlendirme sonucunda o bireyin örgütte kalıp kalmayacağına karar verilmesinden, ücretinde artışa gidilmesine kadar değerleme sonucunda çok önemli kararlar alınır. Bu süreci örgütler ne kadar başarılı uygularlarsa, insan kaynaklarından elde edecekleri verimde o kadar artacaktır (Tortop vd., 2013: 280). İşletme sahipleri ve yöneticiler, belirli zaman dilimlerinde iş görenlerin işlerindeki başarıları değerlendirirler ve elde ettikleri verilere göre hem işletmenin stratejilerini belirlerler hem de çalışanlarının durumları ile ilgili kararlar alırlar. Örneğin; personelin terfi ettirilmesi, işten çıkarılması, kursa ya da eğitime tabi tutulması, ücretlendirme, ödüllendirme gibi kararlar performans değerleme sonuçlarına göre yapılmaktadır. Kısaca açıklarsak, performans değerleme sonuçları kurum ve personel adına karar vermede yöneticilere büyük kolaylıklar sağlar (Güney, 2014: 188).

Yukarda belirtilen konulardan da anlaşılacağı gibi, sistemin asıl amaçlarını bireysel performansın sağlıklı, adaletli ve standart kriterler aracılığıyla belirlenerek ölçülmesi, bu konuda personele bilgi verilmesi ve kişisel performansın geliştirilerek örgütsel etkinliğin arttırılması oluşturulmaktadır (Uyargil, 2015: 215).

\section{3. Ödüllendirme}

Ödül, çalışanların işini beklenenden daha iyi yaptığında ve çalışanın davranışını pekiştirdiğinde verilen teşviktir (Yıldırım, 2008: 666). Başka bir ifadeyle ödül, çalışanın sorumluluğu yerine getirmesi, görevini tamamlaması ve kendisinden istenilen hizmeti vermesi sonucunda elde edeceği kazançlar olarak tanımlanmaktadır (Pitts, 1995: 13).

Ödüllendirme sistemi, bir kuruluşun ihtiyaç duyduğu kişileri işe alarak ve o kuruluşta işe devam etmesini sağlayarak, bu kişilerin motivasyonunu ve azmini arttırıp, kurumun hedefine varmasına yardımcı olan stratejiler, politikalar ve sistemler geliştirme ve uygulama yöntemidir (Canman, 1995: 200). Çalışanlara sunulan ödüllerin çeşidi ve özelliği de önemlidir. Ödüller ve cezalar hem maddi hem de manevi olabilirler. Maddi ödüller arasında; para ikramiyeleri, maddi değeri olan hediyeler; ücret zammı, tatil ve tatil firsatları vb. öncelikle sayılabilir. Manevi, sosyal ödüller arasında ise; sözlü taltifler, takdir, otorite çoğalması, terfi gibi ödüller öncelikle sayılabilir. Dikkat edileceği gibi maddi ödüller çoğunlukla ekonomik kaynaklıdır. Manevi ödüller ise çoğunlukla sözlü mesajlar, statü ve yetki ile ilgilidir (Fındıkçı, 2012: 387).

Çalışanların ödüllendirilmesi ve takdir programlarının temel üç aşamasından söz edilebilir: Çalışanların çabalarına karşılık adil ve adaletli kazanımlar sağlayarak, bir eşitlik düzeni meydana getirmek; çalışanların performanslarını sürdürmek ve geliştirmek için çalışanları güdülemek ve kurumun değer verdiği davranışları ve sonuçları açık hale getirmek (Deeprose, 1994: 2). Ödüllendirme sisteminin bir diğer amacı, kuruluşun stratejik hedeflerine ulaşmasına yardımcı olabilecek yüksek kaliteli bir işgücünü elinde tutmasına ve geliştirmesine yardımcı olmaktır. Gelişmeyi sağlaması için, sistemin stratejik olarak önemli alanlarda kendilerini sürekli geliştiren donanımlı çalışanlara adil ödüller sağlaması gerekmektedir (Lawler, 2000: 106).

\subsection{Personel Güçlendirme}

Personel güçlendirme kavramı ayrıntılı olarak incelendiğinde, yetki devri, yönetime katılım, motivasyon ve iş zenginleştirme kavramları ile bağlantısı olduğu görülmektedir. Personel güçlendirmenin diğerlerine göre farkı, daha geniş ve daha kapsamlı oluşu ve uygulamaya geçilmesinin diğerleri kadar kolay olmaması ve zor olmasıdır (Koçel, 2005: 414). Personel güçlendirme; iş birliği, paylaşma, eğitim ve ekip çalışması yoluyla bireylerin karar verme otoritesini arttırma ve bireyleri geliştirme aşaması olarak da belirtilebilir. Güçlendirme yetkisinin alt kademelere dağıtılmasından daha geniş bir kavramdır. Yetki verilmesinin yanında, astlarda kurumun amaçlarına ulaşmak için sorumluluk alma ve yeteneklerini en iyi şekilde kullanma konusunda da isteklendirmeyi içerir (Aşan ve Aydın, 2006: 281).Personel güçlendirme, hem kurumsal ilişkiler bakımından hem de güdülenme açısından ele alındığı için farklı tanımlar ve konuyu ele alış biçimi ortaya çıkmaktadır. Bir ilişkiler şekli bakımından değerlendirildiği zaman güçlendirme, yöneticinin sahip olduğu güç, yetki ve kontrolü göreceli olarak daha az gücü olan çalışanlara aktarmasıdır. Motivasyon açısından bakıldığında ise, çalışanın işe sadakatini, işe ve kurumuna dâhil olumlu hislerini güçlendirmeye yönelik ruhsal bir yatırım olarak da niceliğini ve niteliğini saptamaktır (Genç, 2004: 223). 
İşletmeleri personel güçlendirme uygulamalarına yönelten en temel neden, değişen tüketici istek ve ihtiyaçları ile küreselleşen ve artan rekabet baskısında, güçlendirmenin personelin daha etkili ve verimli olmalarını sağlayabilecek önemli bir stratejik yönetim anlayışı olmasıdır. Diğer önemli bir neden ise çalışanların artık çok daha eğitimli ve yüksek hedefe sahip, beklentileri artmış çalışanlar haline gelmeleridir (Sökmen, 2014: 396). Personel güçlendirme kuruma ve çalş̧ana birçok fayda sağlamaktadır. Kendisine hem güvenen hem de kendisini güvende hisseden bir çalışan, kuruma daha faydalı olur. Görevler, yetkiler ve sorumluluklar aynı çalışanda olduğunda kendisini daha iyi geliştirecek, yetenek ve yaratıcılığı artacak, denetim mekanizmasına bile ihtiyaç duymadan kendisini kontrol edebilecek, bu nedenle hem çalışan hem de kurum kazançlı çıkacaktır. Enerjiler sinerjiye dönüşecektir. Kurumda alınan kararlar hızlı bir şekilde alınacak, yapılan işte ve işlerde esneklik artacak, iç ve dış müş̧eri memnuniyeti artacak, kurumda hantallık bitecek ve hareketlilik hızlanacak, organizasyon değişim kazanacak, rekabet gücü artacak, alternatif ürün ve iş firsatları ortaya çıkacaktır. Yeni teknolojik firsatların kullanımı artacak, kapalı bilgiler açık olacak, bilgi paylaşımı artacak, bilişim teknolojilerinden yararlanılacak ve rekabet gücü artacaktır. Sonuç olarak güçlendirilmiş kurum veya kuruluşlarda, hem kurum kazanacak hem de çalışanlar kazanacak ve ayrıca ürün veya hizmetten yararlananlar kazanacaktır (Çuhadar, 2005: 4).

\section{5. İş Tatmini}

İş tatmini genel olarak çalışanların gerçekleştirdikleri işin, denetim, ücret, çalışma koşulları, çalışanların kendilerini geliştirme imkânları, sosyal ilişkiler ve iş çevresi gibi çeşitli etkenlere ilişkin olumlu hissetmenin bir sonucu olarak oluşan bir memnuniyet durumu olarak düşünülebilir (Çetin ve Basım, 2011: 84). İş tatmini, kişinin işine yönelik tepki ya da duygularının toplamıdır. Bir başka tanımda iş tatmini kişinin işine karşı sergilediği genel tutumlardır. Fakat çalışanın bu tutumu, olumlu veya olumsuz olabilmektedir. $\mathrm{O}$ halde iş tatmini, kişinin iş tecrübelerinde beliren ruh hali olarak düşünülürken, çalışanın işine karşı duyduğu olumsuz tepkiler ise iş tatminsizliği olarak tanımlanabilir (Erdoğan, 1999: 231). İş tatmini, organizasyon ve kişi arasındaki var olan iyi bir denge, uyum düzeyi ve algılamalardan doğar ve iş çevresindeki denetim yöntemleri, izlenen politika, iş grubu üyeliği, çalışma koşulları, terfi imkânları gibi faktörlerden oluşur. Bir birey yüksek düzeyde tatmin olmuş ise olumlu tutum ve davranışlar gösterir, tatmin derecesi düşükse işine karşı tutum ve davranışları olumsuzdur (Price ve Muller, 1981: 545). Yani iş tatmini çalışan kişi ile iş çevresi arasında olumlu etkileşim ve algılama sonucu oluşurken, tersi durumda da tatminsizlik ortaya çıkar(Çiftyıldız, 2015: 42-43).

İş tatminin önemi 1930 'lu yıllarda Hawthorne araştırmalarıyla anlaşılmaya başlanmıştır. İş tatminin önemi son yıllarda iki nedenden dolayı artmıştır. Birincisi, çalışanların işleri hakkındaki düşüncelerinin ve algılarının bilinmesi isteğidir. İkincisi ise yöneticiler tarafından çalı̧anların işleri hakkındaki tutumlarının, performans, verimlilik, yaratıcılık gibi sonuçlara olan etkisinin bilinmesi isteğidir (Türk, 2007: 69). Kurumlar, çalışanın kuruma katılmasıyla yazılı olmayan bir psikolojik anlaşmaya girerler. Bu psikolojik anlaşma, ücretler ve çalışma koşullarına ilişkin ekonomik anlaşmaya ilavedir. Eğer örgüt yalnızca ekonomik anlaşmaya önem verip, yazılı olmayan psikolojik anlaşmaya gereken önemi vermezse, çalışanlar işe yönelik ilgilerini yitirmeye başlarlar. Çünkü burada motivasyon önemli bir yer kapsamaktadır. Yönetici ile çalışan arasında sadece işe değil, çalışanların duygularına da hitap etmesi gerekir. Yöneticiler çalışanlarını gözlemleyerek iş tatminleri hakkında bilgi edinebilirler. Çalışanın yaptığı iş sonucunda bir beklentisi vardır. Başarıya ulaştığında bundan büyük haz duyar ve bu duygu çalışan kişiyi motive ederek iş tatminini gerçekleştirmiş olur. İş tatmini veya doyumu genel olarak çalışan kişilerin işlerinden hoşlanma durumlarını ifade eder (Price ve Muller, 1981: 545).

İş tatmini özellikle hizmet sektöründe müşteri memnuniyetini arttırarak kurumun başarı göstermesinde etkili olmaktadır. İnsanın insana hizmet sunduğu sektörlerde, çalışanların tutum ve davranışları mal ve hizmetin sunumunda kalitenin belirleyicisi olduğu belirtilmektedir (Ehtiyar, 1996: 109-121). Kurumlar, çalışanların iş tatminini arttırabilmek için bazı yönetimsel stratejiler uygulamaktadırlar. İş tatminini arttırmaya yönelik gösterilen çabaların sonucunda, iş tatminini yüksek düzeyde yaşayan çalışanların performanslarında ve iş faaliyetlerinde olumlu sonuçlar olmaktadır (Sevimli ve İşcan, 2005: 55). Yoon ve Suh (2003) iş tatmini oluşmuş çalışanların daha fazla çalıştıklarını daha kaliteli bir hizmet sunduklarını, çalıştıkları kurumla ilgili ilişkilerinin güçlendiği ve görevlerini daha kaliteli yapmak için eğilimlerinin arttı̆̆ını belirtmişlerdir.

\subsection{Bireysel Performans}

Performans yabancı kökenli bir anlamdır. Türkçe karşılığında edim, başarı olarak kullanılmaktadır. Ancak, günlük konuşma ve yazı dilinde olduğu gibi, performans kelimesi insan kaynakları yönetimi alanında daha yoğun bir şekilde kullanılmaktadır (Çalık, 2003: 7). Yönetim bilimi açısından "performans" kavramı, önceden belirlenen amaçlara ve standartlara uygun olarak bir faaliyetin yerine getirilmesi ya da iş görenin bir işte gösterdiği başarıyı ifade etmektedir. Başka bir ifadeyle, bir işi icra eden bir kişinin, bir toplumun ya da bir kurumun o işle amaçlanan gayeye yönelik olarak neyi sağlayabildiğinin nicel (miktar) ya da nitel (kalite) olarak ifade edilmesidir (Baş ve Atar, 1990: 13). Kamu kurumlarında performans, bir kamu kurumunun başkalarına göre veya kendi geçmişine göre daha etkili ve verimli olmasını kapsamaktadır (Usta, 2010: 34-37).

Bireysel performans, çalışanların örgütün hedeflerine ulaşması adına örgütün onlardan beklentilerini yerine getirmelerine dönük en üst düzeyde çaba göstermeleri ve ortaya konan bu çabadan elde edilen çıktıların yine örgütün 
amaçlarına ve hedeflerine paralellik göstermesidir (Özpehlivan, 2015: 136). Çalışanların bireysel iş performansları yükseldikçe kurumun performansı da yükselir. Kurumların örgütsel hedeflerine ulaşabilmeleri için en önemli unsur çalışanlardır. Bir kurum, çalışanlarının gösterdiği performans düzeyi kadar belirlenen amaçlarına ulaşabilir (Kaya ve Kesen, 2014: 107).

Bireysel performans, örgütsel anlamda önemli görülmekte, bazı sektörlerde ise hayati öneme sahip olduğu varsayılmaktadır. Çalışanların bireysel yetenek ve çalışma yöntemlerinin örgüt çıktılarının alt yapısını oluşturduğu kurumlarda bireysel performans daha ön plana çıkmaktadır (Özpehlivan, 2015: 137). Kurum çalışanları, kurumun hedef ve değerlerini kendilerininkiyle eşleştirdiğinde ve örgütsel hedeflerin kendi idealleriyle örtüştüğünü algıladıklarında bireysel performans düzeylerini en üst seviyeye çıarmak ve görev yaptıkları kuruma daha verimli olmak için kapasitelerini zorlarlar (Miner, 1994: 87). Çalışanların bireysel iş performanslarını etkileyen ve yönetilebilir olduğu düşünülen birçok kişisel, örgütsel ve çevresel faktörlerin olduğu düşünülebilir. Bu değişkenlerin birçok kısmı çalışanların performanslarını olumlu veya olumsuz yönde etkilemektedir. Çalışanın bireysel özellikleri, becerisi, mesleki eğitim düzeyi, kurumun çalışma politikaları, iş tasarımı gibi unsurlar bireysel performans üzerinde etkili olmaktadır (Hayajneh, 2000: 10).

\subsection{Yenilikçi Davranış}

Yenilik kavramı, Latincede yenilenme, yeni yapma ve değiştirme anlamına gelen "innovore" kelimesinden türetilmiş bir kavramdır (Naktiyok, 2007: 213). Yenilik kavramı; yeni fikir, yaklaşım, metot, süreç, yapı, davranış, yetenek ve teknoloji olarak tanımlanır (Kör, 2015: 4). Bir diğer tanıma göre yenilik; yeni süreçleri, ürünleri veya hizmetleri bulmak, geliştirmek, iyileştirmek, adapte etmek ve ticarileştirmektir (Jorde ve Teece, 1992: 48). Yenilikçilik kavramı ise (Jamrog vd., 2006: 5) göre, kurumlarda mevcut olan bilgilerin farklı şekilde kullanımını oluşturmak veya yeni fikirler üreterek fark yaratmak olarak ifade edilebilir. Bu kavram, mevcudun dışında bir ürün veya hizmetin geliştirilmesi şeklinde ifade edilirse eğer, bu durum yeni örgütsel yapıları, yönetim tekniklerini ve yeni iş tarzlarını da kapsar. Yenilikçilikle ilgili çok sayıda tanım bulunmaktadır. Kırım'a göre yenilikçiliğin tanımı, kurumların birbirleriyle rekabet edebilmeleri ve rekabet avantajı sağlayabilmeleri için farklı ve yeni fikirleri uygulamaktır (Kırım, 2007: 5). Barker'e göre ise yenilikçiliğin tanımı; müşterileri tatmin edebilmek için müşterilerin gereksinimlerine yönelik, yenilikçi yeni kaynaklar yaratmaktır (Barker, 2001: 22).

Yenilikçi davranış ise farklı şekillerde tanımlanmış ve açıklanmışır. Bunlardan en tanınanı olan, kişinin içinde bulunduğu çalışma sisteminde yeniliği diğer çalışanlardan daha hızlı bir şekilde bağlanma derecesi olarak gören yaklaşımdır. Başka bir yaklaşımsa, çalı̧̧anın yeni bir ürün veya hizmete yönelik, yenilikçi davranışının bireysel gönüllülüğü olarak söylenebilir (Blake vd., 2003: 156). Yenilikçi iş davranışı, çalışanların çalışma ortamına yeni ve yararlı fikirler, süreçler ve ürünler sunmasını sağlayan bireysel davranıştır (Mura vd. 2012: 2). Ancak, bir tek firsat arayışını ve yeni fikirlerin oluşumunu değil, aynı zamanda değişim ve yeni bilginin uygulanmasını ya da kişisel performansı ve iş performansını geliştirmek için gerekli süreçleri ilerletmeyi amaçlayan davranışları da içine aldığını ortaya koymaktadır (Jong ve Hartog, 2008: 5).

Kurumlar için büyük önem taşıyan yenilikçi iş davranışlarının önemine hem bilim adamları hem de araştırmacılar dikkat çekmiş olsalar da, "çalışanların ne derece yenilikçi iş davranışlarına sahip oldukları ve bu davranışlarını çalışmalarında ne derece kullandıklarının ölçümü" konusunda çalışmalar henüz gelişime devam etmektedir (Jong ve Hartog, 2008: 4). Küreselleşme olgusuyla ortaya çıkan rekabetçi ortamda, kurumların varlıklarını sürdürebilmeleri için yenilikçiliğe açık olan çalş̧anların yanı sıra yenilikçi yönetim stratejilerinin de dâhil edilmesinin gerekliliği giderek daha fazla anlaşılmıştır. Çünkü yoğun rekabet ve teknoloji alanındaki değiş̧imlerin ve gelişmelerin sürekli olarak yenilenmesi, kuruluşları büyük ölçüde etkilemektedir.

\section{Araştırmanın Temel Değişkenleri Arasındaki İlişkiler ve İlgili Hipotezler}

\subsection{Eğitim ile İş Tatmini, Yenilikçi Davranışve Bireysel Performans İlişsisi}

İnsan kaynakları yönetimi alanında eğitim, kişilerin ya da kişilerin oluşturduğu grupların, kurumda üstlendikleri ya da ileride üstlenebilecekleri vazifeleri daha etkili ve kaliteli yerine getire bilmeleri için, çalışanların mesleki bilgi anlayışlarını genişleten, düşünce, akılcı karar alma, davranış ve tutumlarını geliştirme, aynı zamanda da anlayışlarında olumlu değişimler sağlamayı amaçlayan, bilgi, görgü ve becerileri arttıran eğitsel uygulamaların tümünü kapsamaktadır (Sabuncuoğlu, 1994: 124). Literatür incelendiğinde, eğitim; iş tatmini, yenilikçi davranış ve bireysel performans arasındaki ilişkiyi araştıran çalışmaların yapıldığı görülmektedir. Yiğit (2010) yaptığı araştırmasında eğitim ve geliştirme uygulamalarının çalışanların iş tatmini olumlu yönde etkilediği sonucuna varmıştır. Diğer taraftan Sözbilir (2018) yaptığı araştırmada iş başı eğitim uygulamaları, öz-yeterlilik ve yenilikçi davranışı arasındaki ilişkiye bakmıştır. Çalışmada, eğitim uygulamalarının çalışanların yenilikçi davranışı üzerinde olumlu ve anlamlı ilişkisinin olduğu bulgusuna ulaşmıştır. Araştırmacı, eğitim uygulamalarının çalışanların yenilikçi davranışa yönelttiğini belirtmiştir. Başka bir çalışmada Yılmaz (2009), eğitim uygulamalarının çalışanların bireysel performansı üzerinde olumlu ve anlamlı etkisinin olduğu sonucuna varmıştır. Çalışanların kurum içerisinde aldıkları eğitimin, onların gelişmelerini sağlayıp verimliliklerinin artacağını belirtmiştir. Bu açılamalar ışığında, eğitimin; iş tatmini, yenilikçi 
davranış ve bireysel performans üzerinde olumlu etkisinin olup olmadığını test etmek amacıyla, çalışmanın; birinci, ikinci ve üçüncü hipotezleri aşağıdaki gibi kurgulanmıştır:

H1: Eğitim, iş tatminini pozitif yönde etkiler.

$\mathbf{H}_{2}$ : Eğitim, yenilikçi davranışı pozitif yönde etkiler.

$\mathbf{H}_{3}$ : Eğitim, bireysel performansı pozitif yönde etkiler.

\subsection{Performans Değerlendirme ile İş Tatmini, Yenilikçi Davranış ve Bireysel Performans İliş̧kisi}

Günümüzde pek çok kurumun kendi içerisinde bir performans değerleme sistemi oluşturduklarını ve uyguladıklarını görmekteyiz. Çalışanların belirli aralıklarla performansının değerlendirilmesi, hem çalışanlar hem yöneticiler hem de kurum için birçok yarar sağlamaktadır. Çalışanların performansının değerlendirilmesi, en azından çalışanlardan neler beklendiğini, bulunduğu işte gerekli sayılan çalışma standartlarının neler olduğunu, hangi davranışların olumlu olduğu ve hangi davranışların olumsuz olduğunun önceden belirlenmesini mümkün kılar. Bu ölçütlere göre değerlendirilen kişi, güçlü ve zayıf yönleri ile başarı derecesi hakkında bilgi sahibi olur. Böylece kendisini düzeltme ve geliştirme olanağını bulur. Bu durum kişinin, işinden tatmin olmasına ve daha iyisini yapmaya ve daha verimli çalışmaya yöneltmesi demektir (Tutum, 1979: 153-154). Performans değerlendirme; iş tatmini, yenilikçi davranış ve bireysel performans ilişkisi bazı araştırmacılar tarafından ele alınmıştır. Performans değerlendirme ve iş tatmini ilişkisi ile ilgili Yumuşak (2008) çalışmasında, performans değerlendirmenin çalışanların iş tatmini üzerinde pozitif etkisi olduğunu belirlemiş ve çalışanların fikirlerinin ve düşüncelerinin yer verildiği bir değerlendirme sisteminde iş tatminlerinin arttığını belirlemiştir. Performans değerlendirme ile yenilikçi davranış ilişkisi ise, Korkmaz vd. (2018) KOBİ'ler üzerinde yaptıkları alan çalışmasında performans değerlendirmenin yenilikçi davranıı̧ı etkilediği sonucuna ulaşmışlardır. Personeli stratejide tanımlı hedefe odaklayan bir performans ölçüm sistemi geliştirmek ve buna bağlı ödüllendirmeler yapmak, yenilikçi davranış fikirlerinin artırılmasını sağlayacağından bahsetmişlerdir. Performans değerlendirme ile bireysel performans arasındaki ilişki ile ilgili Akçakanat (2009) yapmış olduğu çalışmasında, objektif bir değerlendirme sisteminin kurulmasından söz etmiş ve performans değerlendirmenin çalışanların bireysel performanslarını arttıracağını belirtmiştir. Buradan elde edilen sonuca göre çalışmanın, dördüncü, beşinci ve altıncı hipotezi aşağıdaki gibi kurgulanmıştır:

$\mathbf{H}_{4}$ : Performans Değerlendirme, iş tatminini pozitif yönde etkiler.

H5: Performans Değerlendirme, yenilikçi davranışı pozitif yönde etkiler.

H6: Performans Değerlendirme, bireysel performansı pozitif yönde etkiler.

\section{3. Ödülllendirme ile İs Tatmini, Yenilikçi Davranışve Bireysel Performans İlişkisi}

Kurumlarda çalışanlara yönelik ödüllendirmelerin yapılmasının en önemli amacını, çalışanların hem görevlerini hem de iş yerini severek motivasyonun arttırılmasının sağlanmasını kapsamaktadır (Karatepe, 2005: 125). Çalışanların elde ettikleri başarının yöneticiler tarafından takdirle karşılanması sonucu ödüllendirilmesi, davranış kalıplarının değişmesine, gelişmesine ve yenililerinin orta çıkmasını neden olmaktadır. Ödüllendirilen çalışanın ise, çalışma hayatında daha fazla başarı göstermek üzere, motive olmasına neden olmaktadır (Aktaş, 2002: 48). Ödüllendirme ile ilgili daha önce yapılmış çalışmalara bakıldığında, ödüllendirmenin iş tatmini ile ilgili ilişskisi; Koç (2007) Garp Linyitleri işletmesindeki çalışanlara uygulanan ödül sistemlerinin iş tatmini üzerine etkisini ölçmek için yapmış olduğu araştırmasında ödüllendirmenin iş tatminini etkilediği sonucunu elde etmiştir. Etkin bir ödüllendirme sisteminin çalışanların iş tatminini sağlayacağını belirtmiştir. Ekiyor ve Arslantaş (2015) yapmış oldukları çalışmalarında, ödüllendirmenin çalışanların yenilikçi davranışlarını olumlu yönde etkilediği sonucuna ulaşmışlardır. Maddi (para, hediye) ve manevi (takdir, terfi) gibi ödüllendirmelerin çalışanların yenilikçi iş davranışı sergilediğini belirtmişlerdir. Ödüllendirme ile bireysel performans arasındaki ilişki Akçit (2011) çalışmasında ödüllendirmenin personelin performansına olumlu etkisinin olduğunu ve ödüllendirilen çalışanın bireysel iş performansının arttı̆̆ sonucuna ulaşmışlardır. Buradan elde edilen sonuçlara göre çalışmanın, yedinci, sekizinci ve dokuzuncu hipotezleri aşağıdaki gibi kurulmuştur:

H7: Ödüllendirme, iş tatminini pozitif yönde etkiler.

H8: Ödüllendirme, yenilikçi davranışı pozitif yönde etkiler.

H9: Ödüllendirme, bireysel performansı pozitif yönde etkiler.

\subsection{Personel Güçlendirme ile İş Tatmini, Yenilikçi Davranışve Bireysel Performans İlişkisi}

İnsan ve işgücü faktörlerinin diğer tüm sektörlerden daha büyük bir role sahip olduğu hizmet sektöründe, insan emeğinin verimli bir şekilde kullanılması büyük öneme sahiptir. Hizmet sektöründe çalışan çalışanların daha verimli çalışması için uygun ortamın yaratıldığı ve buna paralel olarak insan kaynakları yönetim politikalarının belirlenmesinin nedenli önemli olduğu ortadadır. Kurumların, bugünün oldukça rekabetçi ortamında çalışanlarıyla misyon ve vizyonlarını paylaşmaları ve tüm çalışanların sürdürülebilir bir rekabet ortamında, rekabetçi bir araç olarak 
kullanılması için stratejik yönetim sürecine katıldığı bir yönetim tarzı olması önemlidir. Bu durum literatürde, üst yönetim birimlerinin aldığı kararların, uygulayıcıları konumundaki çalışanların söz ve inisiyatif almaları bağlamında, çalışanların güçlendirilmesi konusundaki yerini almaktadır (Özer, vd., 2015: 113-114).

Personel güçlendirme, çalışanların yetkilendirilmesinin bir sonucu olarak, yetkilendirilmiş ve daha fazla otorite ile donatılan personel, müşterilere daha hızlı bir şekilde hizmet verebilecek, üst yönetime danışmadan karar verebilecek, çalışanlar işlerinde başarılı olduklarında iş tatminleri artacak, yeni yetenekler geliştirecek, yaratıcı fikirlerini kullanacak ve hizmet alanlarla daha istekli ilgilenip hizmet sunacaktır (Bowen ve Lawyer, 1992; Boddy, 1990). Personel güçlendirme ile iş tatmini, yenilikçi davranış ve bireysel performans ilişkisi ile ilgili yapılan çalışmalarda, Kitapçı, vd. (2013) alan araştırmasında personel güçlendirmenin iş tatmini üzerinde anlamlı etkisinin olduğu sonucuna varmışlar ve güçlendirilen personelin iş tatmininin artacağını belirtmişlerdir. Diğer bir çalışmada Çavuş (2006) personel güçlendirmenin yenilikçi iş davranışı üzerinde anlamlı ve olumlu etkisinin olduğunu belirlemiş ve güçlendirilmiş personelin yenilikçi davranış sergilediğinden bahsetmiştir. Başka bir çalışmada, Bektaş ve Karagöz (2018) yaptıkları araştırmada, personel güçlendirmenin bireysel performansı pozitif etkilediği sonucunu elde etmişlerdir. Güçlendirilmiş personelin verimliliğinin arttığını belirlemişlerdir. Buradan elde edilen sonuçla çalışmanın onuncu, on birinci ve on ikinci hipotezleri aşağıdaki gibi kurulmuştur:

H10: Personel Güçlendirme, iş tatminini pozitif yönde etkiler.

H11: Personel Güçlendirme, yenilikçi davranışı pozitif yönde etkiler.

H12: Personel Güçlendirme, bireysel performansı pozitif yönde etkiler.

\section{Araştırmanın Metodolojisi}

\subsection{Araştırmanın Amacı}

Bu çalışmanın amacı, insan kaynakları yönetimi uygulamalarından; eğitim, performans değerlendirme, ödüllendirme ve personel güçlendirmenin, çalışanların iş tatminine, bireysel iş performansına ve yenilikçi iş davranışına etkisinin olup olmadığını tespit etmektir. Bu bağlamda, Kahramanmaraş’ta faaliyet gösteren bir kamu kurumunda alan araştırması yapılmıştır.

\subsection{Araştırmanın Yöntemi ve Örneklemi}

Araştırma nicel desende kesitsel bir alan araştırması içermektedir. Araştırmanın evrenini Kahramanmaraş ilinde kamu sektöründe faaliyet gösteren bir kurumda 516 çalışan oluşturmuştur. Araştırma için hesaplanan minimum örneklem sayıs 220 'dir.

\subsection{Veri Toplama Süreci ve Aract}

Çalışmada veri toplama aracı olarak anket soru formu kullanılmıştır. Anket formu, çalışanlara elden dağıtılıp toplanarak uygulanmıştır. Anketleri uygulamak amacıyla farklı birimlerde çalışan yaklaşık 300 çalışanla birebir irtibata geçilmiş ve 237 çalışandan cevap alınmıştır. Elde edilen 237 anketten 11'i eksik doldurma nedeniyle çalışmadan çıkarılmış geriye kalan 226 anket analizlerde kullanılmıştır.

Üç bölümden oluşan anket soru formunun ilk bölümünde demografik özellikler (yaş, cinsiyet, eğitim gibi) hakkında bilgi edinmek için sorular yer almıştır. Anketin ikinci kısmı, insan kaynakları yönetimi uygulamaları (Eğitim, Performans değerleme, ödüllendirme gibi) hakkında sorular içermektedir ve çalışanlardan katılım derecelerini belirtmeleri istenmiştir. Anketin üçüncü bölümündeki sorularda çalışanların iş tatminini, yenilikçi davranış ve bireysel performansını belirlemeye yönelik olup katılma derecelerini belirtmeleri istenmiştir. Araştırmada ikinci ve üçüncü bölümde kullanılan ölçekler ise şu şekildedir;

Eğitim ölçeği: Eğitim ölçeği altı maddelik bir ölçek olup, bu çalışmada Yılmaz (2012) tarafından kullanılmış olan ölçekten yararlanılmıştır.

Performans değerlendirme ölçeği: Performans değerlendirme ölçeği, Guest, Michie, Conway\&Sheehan, (2003)tarafından yapılan çalışmada kullanılan üç maddelik ölçek olup, Kuzutürk (2016) tarafindan uyarlanan ölçek bu çalışmada da kullanılmıştır.

Ödüllendirme ölçeği: Ödüllendirme ölçeği Chin-Ju Tsai. (2006) tarafından yapılan çalışmada geliştirilen dört maddelik bir ölçek olup, Kuzutürk (2016) tarafindan uyarlanan ölçek bu çalışmada da kullanılmıştır.

Personel güçlendirme ölçeği: Spreitzer (1995)'den alınan 12 maddeden oluşur. Güçlendirmenin dört boyutunun her birini ölçmek için üç ifade kullanıldı. Bu ölçek Çöl (2008) tarafından da kullanılmıştır.

Bireysel performans ölçeği: Çalışanların iş performansı ölçeği, önce Kirkman ve Rosen (1999) daha sonra, Sigler ve Pearson (2000) tarafından yapılan çalışmalarda kullanılan dört maddelik ölçek kullanılmıştır. Bu ölçek Çöl (2008) tarafından da kullanılmıştır.

İş tatmini ölçeği: Hackman ve Oldham'ın (1975) çalışmasından uyarlanan beş maddeli bir ölçek olup, Türkçeye Basım ve Şeşen (2009) tarafından uyarlanmış ve bu çalışmada kullanılmıştır. 
Yenilikçi davranış ölçeği: De Jong ve Den Hartog (2010)'un geliştirdiği on maddelik ölçekten faydalanılmıştır. Daha önce, Kör (2015) tarafindan da uygulanan ölçek bu çalışmada da kullanılmıştır.

Araştırma kapsamında ele alınan üç değişkeni ölçmek adına oluşturulan anket soru formu, beşli Likert ölçeğine göre hazırlanmıştır. Ölçekler; 1: Kesinlikle katılmıyorum, 2: Katılmıyorum, 3: Kararsızım, 4: Katılıyorum, 5: Kesinlikle katılıyorum, şeklindedir. Araştırmada, araştırma modelindeki üç değişkeni ölçmek için kullanılan ölçekler, geçerliliği ve güvenilirliği onaylanmış ölçeklerdir.

Araştırmada kullanılan ölçeklerin güvenilirlik analizleri, iç tutarlılık Cronbach’s Alpha katsayıların hesaplanması ile yapılmış, bu analize ait sonuçlar Tablo 1'de gösterilmiştir.

Tablo 1. Araştırmada Kullanılan Ölçeklerin Güvenilirlik Değerleri

\begin{tabular}{|l|c|c|c|}
\hline Değişkenler & Soru Sayısı & Çıkarılan Soru & Alpha Katsayısı \\
\hline Eğitim & 6 & - &, 925 \\
\hline Performans Değerlendirme & 3 & - &, 864 \\
\hline Ödüllendirme & 4 & - &, 866 \\
\hline Personel Güçlendirme & 12 & - &, 851 \\
\hline İş Tatmini & 5 & - &, 871 \\
\hline Bireysel Performans & 4 & - &, 880 \\
\hline Yenilikçi davranış & 10 & - &, 932 \\
\hline
\end{tabular}

Uygulanan güvenlik analizi sonucunda, eğitim ölçeğinin Cronbach’s Alpha değeri ,925 performans değerlendirme ölçeğinin Cronbach's Alpha değeri ,864 ödüllendirme ölçeğinin Cronbach’s Alpha değeri ,866 personel güçlendirme ölçeğinin Cronbach's Alpha değeri ,851 iş tatmini ölçeğinin ,871 bireysel performans ölçeğinin Cronbach's Alpha değeri ,880 ve yenilikçi davranış ölçeğinin Cronbach's Alpha değeri ,932 olarak bulunmuştur. Güvenilirlik analizi sonuçları beklentileri karşılamaktadır. Tüm değişkenlerin literatürde kabul gören ,70 oranının üstünde olduğu görülmüştür (Kaya ve Kesen 2014: 112). Bu değişkenlerin hepsi,70'in oldukça üstünde olduğundan iyi düzeyde geçerliliği kabul edilmiştir.

\subsection{Araştırmanın Modeli}

Araştırmanın modeli Şekil 1'deki gibidir.

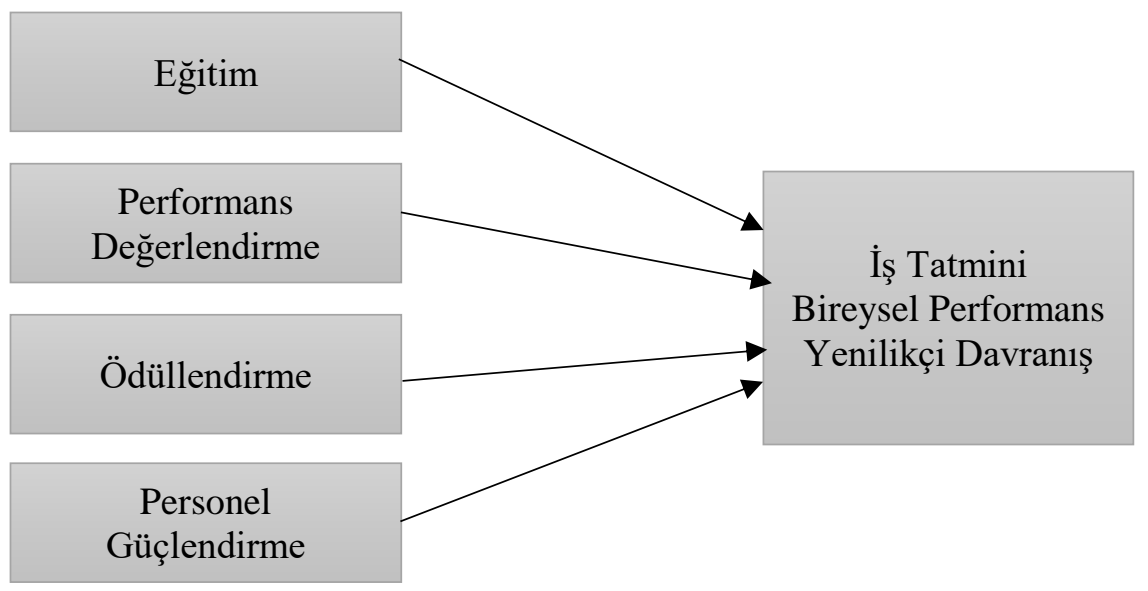

Şekil 1. Araştırmanın Modeli

\subsection{Verilerin Analizi}

Araştırmadan elde edilen veriler SPSS 23.0 istatistik programı ile analiz edilmiştir. Araştırma ölçeklerinin güvenilirliğini test etmek için Cronbach Alpha ile iç tutarlılık analizi yapılmıştır. Araştırma hipotezlerini doğrulanmak için, regresyon analizinden önce değişkenler arasındaki ilişkileri ortaya çıkartmak için, korelasyon analizi yapıldı. Bağımsız değişkenlerin (eğitim, performans değerlendirme, ödüllendirme ve personel güçlendirme), bağımlı değişken (iş tatmini, yenilikçi davranış ve bireysel performans) üzerindeki etkisini göstermek için çoklu regresyon analizi kullanılmıştır. 


\section{Araştırmanın Bulguları}

Çalışmanın bu bölümünde, elde edilen verilerin istatistiksel analiz sonuçlarına yer verilmiştir. Sıra ile araştırmada kullanılan ölçeklerin güvenilirlik değerlerine, çalışanların demografik özelliklerine ilişkin frekans analizine ve hipotezlerin test edilmesinde kullanılan korelasyon ve regresyon analizlerine yer verilmiş ve bulgular değerlendirilmiştir

\subsection{Demografik Özelliklere İlişkin Bulgular}

Çalışanların demografik özelliklerine ilişkin frekans analizi yapılmış ve sonuçlar aşağıdaki Tablo 2'de sunulmuştur.

Tablo 2. Araştırmaya Katılanların Demografik Özellikleri

\begin{tabular}{|c|c|c|c|}
\hline Değişkenler & Kategoriler & Frekans & $\%$ \\
\hline \multirow[t]{2}{*}{ Cinsiyet } & Erkek & 144 & 63,7 \\
\hline & Kadın & 82 & 36,3 \\
\hline \multirow[t]{5}{*}{ Yaş } & 20-24 yaş & 5 & 2,2 \\
\hline & $25-29$ & 23 & 10,2 \\
\hline & $30-34$ & 55 & 24,3 \\
\hline & $35-39$ & 46 & 20,4 \\
\hline & 40 ve üstü & 97 & 42,9 \\
\hline \multirow[t]{2}{*}{ Medeni Durum } & Evli & 185 & 81,9 \\
\hline & Bekâr & 41 & 18,1 \\
\hline \multirow{5}{*}{$\begin{array}{l}\text { Çalışanların } \\
\text { Kurumdaki } \\
\text { Hizmet Süresi }\end{array}$} & $1-5 \mathrm{y} 1 \mathrm{l}$ & 71 & 31,4 \\
\hline & 6-10 y1l & 58 & 25,7 \\
\hline & $11-15$ y1l & 28 & 12,4 \\
\hline & $16-20 \mathrm{y} 1 \mathrm{l}$ & 33 & 14,6 \\
\hline & 21 ve üstü & 36 & 15,9 \\
\hline \multirow{5}{*}{$\begin{array}{l}\text { Çalışanların Toplam } \\
\text { Hizmet Süresi }\end{array}$} & $1-5$ yil & 35 & 15,5 \\
\hline & $6-10 \mathrm{y} 11$ & 67 & 29,6 \\
\hline & $11-15$ y1l & 38 & 16,8 \\
\hline & $16-20$ y1l & 29 & 12,8 \\
\hline & 21 ve üstü & 57 & 25,2 \\
\hline \multirow[t]{5}{*}{ Öğrenim Düzeyi } & Lise & 23 & 10,2 \\
\hline & Ön Lisans & 37 & 16,4 \\
\hline & Lisans & 120 & 53,1 \\
\hline & Lisansüstü & 41 & 18,1 \\
\hline & Diğer & 5 & 2,2 \\
\hline \multirow{4}{*}{$\begin{array}{l}\text { Katılımcıların } \\
\text { Çalıştığı } \\
\text { Birime Göre Dağılım }\end{array}$} & Fakülte & 76 & 36,6 \\
\hline & Enstitü & 18 & 8,0 \\
\hline & Daire Başkanlığı & 85 & 37,6 \\
\hline & Hastane & 47 & 20,8 \\
\hline
\end{tabular}

Tablo 2'ye göre araştırmaya katılan 226 çalışanın, \%63,7'si erkeklerden oluşmakta, \%42,9'u 40 ve üstü yaş gurubunda yer almakta, \%81,9'u evli, \%31,4'ü 1-5 yıl arasında kurumda hizmet vermekte. \%29,6'sı 6-10 yıl arasında toplam hizmet süresine sahiptir. Katılımcıların \%53'i lisans mezunlarından oluşmakta, \%37,6'sı daire başkanlığ biriminde görev yapmaktadır.

\subsection{Faktör Analizi Bulgulart}

$\mathrm{Bu}$ bölümde insan kaynakları yönetimi uygulamalarından; eğitim, performans değerlendirme, ödüllendirme ve personel güçlendirme değişkenlerine ilişkin faktör analizine yer verilmiştir. Elde edilen sonuçlar Tablo 3 ve 4 'te gösterilmiştir.

Tablo 3’te gösterilen insan kaynakları yönetimi uygulamaları ölçeği incelendiğinde faktör analizi yapabilmenin ön şartlarından birincisi olan KMO (Kaiser-Meyer-Olkin) testi faktör analizi için yeterli örneklem büyüklüğüne ulaşılıp ulaşılmadığını göstermektedir. Bu değer 0,871>0,80 olduğu için iyi bir örneklem büyüklüğüne ulaşıldığı tespit edilmiştir. İkinci şart olan Bartlett's küresellik testinin anlamlı çıkması sig. ,000<0,01 ise boyutları oluşturan ifadelerin birbirleriyle tutarlı ve değişkenler arasında ilişki olduğunu göstermektedir. 
Tablo 3. İKY Sorularına İlişkin KMO Örneklem Yeterliliği Ölçüm Analizi ve Barlett Testi Sonuçları Kaiser-Meyer-Olkin örneklem yeterliliği ölçüm analizi Bartlett küresellik testi

\begin{tabular}{|l|c|} 
Ki kare (Approx. Chi-Square) & $\mathbf{, 8 7 1}$ \\
\hline Serbestlik derecesi (df) & 4335,029 \\
\hline Önem (Sig.) & 300 \\
\hline
\end{tabular}

Tablo 4. İnsan Kaynakları Yönetimi Uygulamaları Faktör Analizi Sonuçları

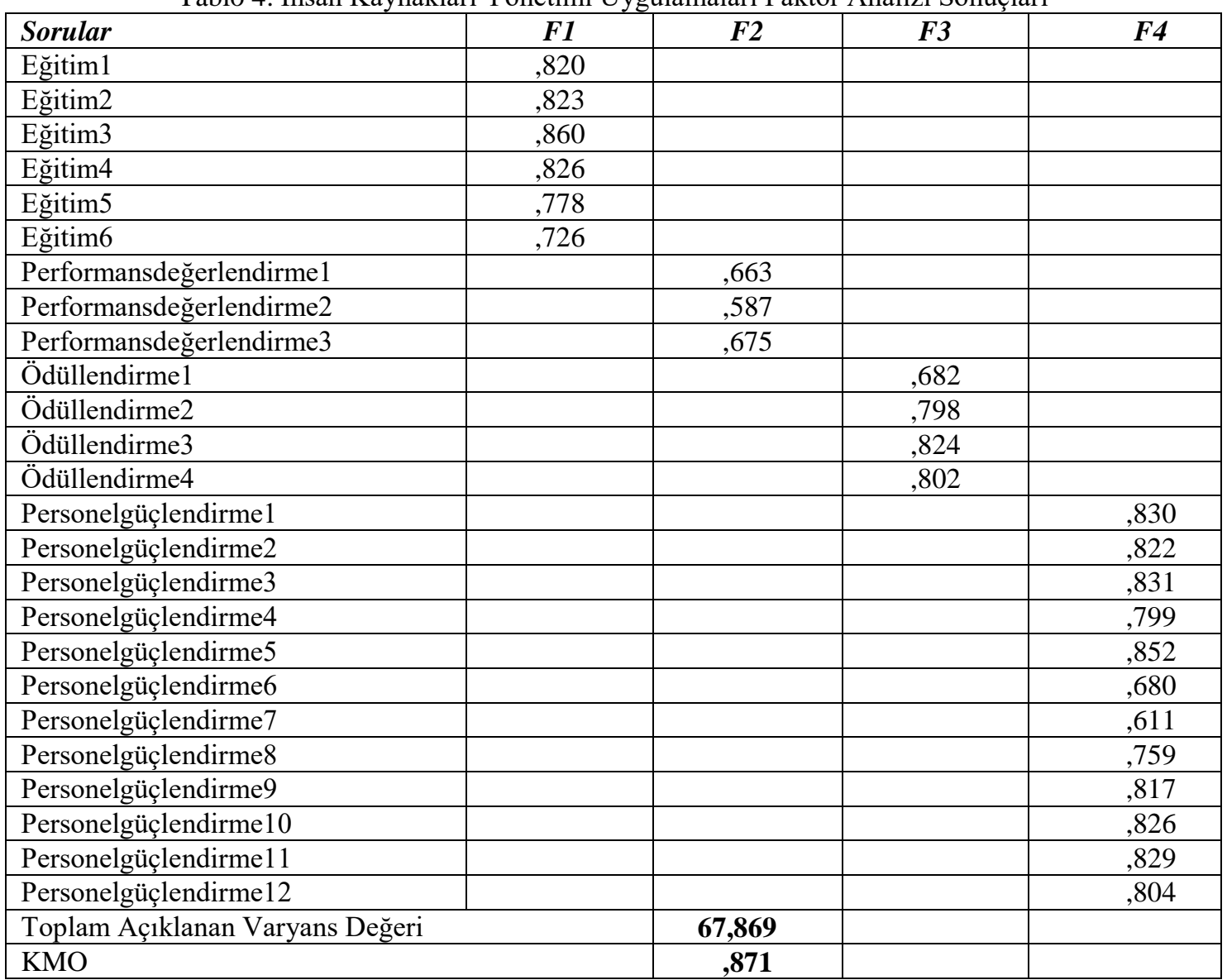

Tablo 4'ten de görülebileceği üzere, insan kaynakları yönetimi uygulamaları ölçeği dört ayrı boyuta ayrılmıştır. $\mathrm{Bu}$ boyutlara giren ifadeler ve aldıkları faktör yükleri de yine tablodan görülebilir. Her bir boyuta ilişkin ifadeler birbirleriyle anlamlı ve tutarlı bir şekilde kümeleştirildiğinde bu dört boyut sırasılyla eğitim, performans değerlendirme, ödüllendirme ve personel güçlendirme olarak doğrulanmıştır. Açıklanan varyans yaklaşık \%67,869 çıkmıştır.

Çalışmada ayrıca iş tatmini, bireysel performans ve yenilikçi davranış ölçeklerine ilişkin faktör analizi yapılmıştır. Sonuçlar Tablo 5 ve Tablo 6'da gösterilmiştir. Bu kapsamda öncelikle KMO ve Barlett's testi yapılmıştır. İş tatmini, bireysel performans ve yenilikçi davranış faktör analizi sonuçlarına baktığımızda, faktör analizi yapabilme ön şartları olan KMO (Kaiser-Meyer-Olkin) 0,899>0,80 çıktığı için iyi bir örneklem büyüklüğüne ulaşıldığını göstermektedir. Bartlett's küresellik test değeri sig. , $000<0,01$ çıktığı için boyutları oluşturan ifadelerin birbirleriyle tutarlı ve değişkenler arasında ilişki olduğunu ifade etmektedir.

Tablo 5. İş Tatmini, Bireysel Performans ve Yenilikçi Davranış Sorularına İlişkin KMO Örneklem Yeterliliği Ölçüm Analizi ve Barlett Testi Sonuçları.

\begin{tabular}{|l|l|c|}
\hline \multicolumn{2}{|l|}{ Kaiser-Meyer-Olkin örneklem yeterliliği ölçüm analizi } & $\mathbf{8 9 9}$ \\
\hline \multirow{3}{*}{ Bartlett küresellik testi } & Ki kare (Approx. Chi-Square) & 3104,208 \\
\cline { 2 - 3 } & Serbestlik derecesi (df) & 171 \\
\cline { 2 - 3 } & Önem (Sig.) &, 000 \\
\hline
\end{tabular}

Tablo 6. İş Tatmini, Bireysel Performans ve Yenilikçi Davranış Faktör Analizi Sonuçları

\begin{tabular}{|l|c|c|c|}
\hline Sorular & $\boldsymbol{F 1}$ & $\boldsymbol{F 2}$ & $\boldsymbol{F 3}$ \\
\hline İştatmini1 &, 561 & & \\
\hline İștatmini2 &, 799 & & \\
\hline İştatmini3 &, 850 & & \\
\hline
\end{tabular}




\begin{tabular}{|c|c|c|c|}
\hline İştatmini4 & ,866 & & \\
\hline İştatmini5 &, 872 & & \\
\hline Bireyselperformans1 & &, 774 & \\
\hline Bireyselperformans2 & & 833 & \\
\hline Bireyselperformans 3 & & ,799 & \\
\hline Bireyselperformans 4 & & 779 & \\
\hline Yenilikçidavranış1 & & & ,567 \\
\hline Yenilikçidavranış2 & & & ,562 \\
\hline Yenilikçidavranış3 & & &, 705 \\
\hline Yenilikçidavranış4 & & &, 771 \\
\hline Yenilikçidavranış5 & & & ,791 \\
\hline Yenilikçidavranış6 & & &, 741 \\
\hline Yenilikçidavranış7 & & &, 832 \\
\hline Yenilikçidavranış8 & & &, 822 \\
\hline Yenilikçidavranış9 & & & ,826 \\
\hline Yenilikçidavranış10 & & &, 839 \\
\hline Toplam Açıklanan Varyans Değeri & & 67,472 & \\
\hline KMO & &, 899 & \\
\hline
\end{tabular}

Tablo 6'da iş tatmini, bireysel performans ve yenilikçi davranış ölçeğinin faktör analiz sonuçlarını göstermektedir. Tablodan da görülebileceği üzere faktör yükleri üç ayrı boyuta ayrılmıştır. Bu boyutlara giren ifadeler ve aldıkları faktör yükleri de yine tablodan görülebilir. Bu üç değişkenin (iş tatmini, bireysel performans ve yenilikçi davranış) açıklanan varyansı \% 67,472 çıkmıştır.

\subsection{Korelasyon Bulgulart}

Eğitim, performans değerlendirme, ödüllendirme, personel güçlendirmenin; iş tatmini, bireysel performans ve yenilikçi davranış arasındaki ilişkiyi test etmek için korelasyon analizi yapılmış ve bu sonuçlar aşağıda Tablo 7 'de gösterilmiştir. Analiz sonucunda değişkenler arasındaki korelasyon katsayıları belirlenmiştir.

Tablo 7. Korelâsyon Analizi Sonuçları

\begin{tabular}{|c|c|c|c|c|c|c|c|c|c|}
\hline & 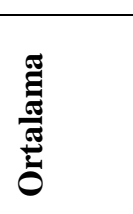 & 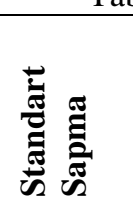 & (1) & (2) & (3) & (4) & (5) & (6) & (7) \\
\hline \multirow[t]{3}{*}{ (1) Eğitim } & \multirow{3}{*}{2,8968} & \multirow{3}{*}{1,02024} & 1 & & & & & & \\
\hline & & & & & & & & & \\
\hline & & & 226 & & & & & & \\
\hline \multirow{3}{*}{$\begin{array}{l}\text { (2) Performans } \\
\text { Değerlendirme }\end{array}$} & \multirow{3}{*}{2,5723} & \multirow{3}{*}{1,08500} & ,609** & 1 & & & & & \\
\hline & & & ,000 & & & & & & \\
\hline & & & 226 & 226 & & & & & \\
\hline \multirow{3}{*}{$\begin{array}{l}\text { (3)Ödüllendirm } \\
\text { e }\end{array}$} & \multirow{3}{*}{2,1538} & \multirow{3}{*}{1,04954} &, $456 * *$ &, $635^{* *}$ & 1 & & & & \\
\hline & & & , 000 & , 000 & & & & & \\
\hline & & & 226 & 226 & 226 & & & & \\
\hline \multirow{3}{*}{$\begin{array}{l}\text { (4) Personel } \\
\text { Güçlendirme }\end{array}$} & \multirow{3}{*}{3,5693} & \multirow{3}{*}{,65949 } &, $276 * *$ & $298^{* *}$ & ,204** & 1 & & & \\
\hline & & & , 000 & ,000 & ,002 & & & & \\
\hline & & & 226 & 226 & 226 & 226 & & & \\
\hline \multirow[t]{3}{*}{ (5) İş Tatmini } & \multirow{3}{*}{17,2566} & \multirow{3}{*}{4,60199} &, $271 * *$ &, $205^{* *}$ &, $188 * *$ &, $446^{* * *}$ & 1 & & \\
\hline & & & , 000 & ,002 & ,005 & , 000 & & & \\
\hline & & & 226 & 226 & 226 & 226 & 226 & & \\
\hline \multirow{3}{*}{$\begin{array}{l}\text { (6) Bireysel } \\
\text { Performans }\end{array}$} & \multirow{3}{*}{4,1250} & \multirow{3}{*}{,74991 } & ,079 & ,036 &,- 102 &, $371 * *$ &, $371 * *$ & 1 & \\
\hline & & & ,235 & ,595 & ,127 & ,000 & ,000 & & \\
\hline & & & 226 & 226 & 226 & 226 & 226 & 226 & \\
\hline \multirow{3}{*}{$\begin{array}{l}\text { (7) Yenilikçi } \\
\text { Davranış }\end{array}$} & \multirow{3}{*}{3,7403} & \multirow{3}{*}{,73031 } & ,148* &, 118 & ,098 &, $446^{* * *}$ &, $382 * *$ &, $561 * *$ & 1 \\
\hline & & &, 026 & ,077 & ,141 & ,000 & ,000 & ,000 & \\
\hline & & & 226 & 226 & 226 & 226 & 226 & 226 & 226 \\
\hline
\end{tabular}

** Correlation is significant at the 0.01 level (2-tailed).

* Correlation is significant at the 0.05 level (2-tailed). 
Korelasyon analizi değerlendirildiğinde, eğitimin $(\mathrm{r}=, 271 ; \mathrm{p}<0,01)$ iş tatmini ve yenilikçi davranış $(\mathrm{r}=, 148$; $\mathrm{p}<0,05)$ ile pozitif ilişkisi vardır. Eğitimin $(\mathrm{r}=, 079 ; \mathrm{p}>0,05)$ bireysel performans ile arasında ilişki yoktur. Performans değerlendirmenin $(r=, 205 ; p<0,01)$ iş tatmini ile pozitif ilişkisi olup, bireysel performans $(r=, 036 ; p>0,05)$ ve yenilikçi davranış $(r=, 118 ; p>0,05)$ arasında iliş̧ki yoktur. Ödüllendirmenin $(r=188 ; p<0,01)$ iş tatmini ile pozitif ilişkisi olup, bireysel performans $(\mathrm{r}=-, 102 ; \mathrm{p}>0,05)$ ve yenilikçi davranış $(\mathrm{r}=, 098 ; \mathrm{p}>0,05)$ arasında ilişki yoktur. Personel güçlendirmenin $(r=, 446 ; p<0,01)$ iş tatmini, $(r=, 371 ; p<0,01)$ bireysel performans ve $(r=, 446 ; p<0,01)$ yenilikçi davranış arasında pozitif ilişki vardır.

\subsection{Regresyon Bulgulart}

Çalışmanın hipotezlerini test etmek için çoklu regresyon analizi yapılmış ve sonuçlara yer verilip değerlendirilmiştir. Başka bir ifadeyle, bağımsız değiş̧kenlerin bağımlı değişkenlere etkisini test etmek için regresyon analizi yapılmış, sonuçlara ve değerlendirmelere aşağıda yer verilmiştir.

Araştırmanın birinci " $\mathrm{H}_{1}$ : Eğitim, iş tatminini pozitif yönde etkiler", dördüncü " $\mathrm{H}_{4}$ : Performans değerlendirme, iş tatminini pozitif yönde etkiler", yedinci " $\mathrm{H}_{7}$ : Ödüllendirme, iş tatminini pozitif yönde etkiler." ve onuncu " $\mathrm{H}_{10}$ : Personel güçlendirme, iş tatminini pozitif yönde etkiler" hipotezlerini test etmek için çoklu regresyon analizi yapılmış ve sonuçlar Tablo 8'de gösterilmiştir.

Tablo 8. İnsan Kaynakları Uygulamalarının İş Tatminine Etkilemesine İlişkin Regresyon Analizi ve Sonuçları

\begin{tabular}{|l|c|c|c|c|c|c|c|c|}
\hline Model & $\begin{array}{c}\text { Standartlaşma } \\
\text { mış } \\
\text { Katsayılar } \\
\mathbf{B}\end{array}$ & $\begin{array}{c}\text { Standart } \\
\text { Hata }\end{array}$ & $\begin{array}{c}\text { Standart } \\
\text { laşmıs } \\
\text { Katsayılar } \\
\text { (Beta) } \boldsymbol{\beta}\end{array}$ & $\mathbf{T}$ & $\mathbf{P}$ & $\mathbf{F}$ & $\mathbf{R}^{2}$ & $\Delta \mathbf{R}^{2}$ \\
\hline Sabit & 5,036 & 1,552 & & 3,244 &, 001 & & & \\
\hline Eğitim &, 740 &, 341 &, $164^{* *}$ & 2,167 &, 031 & 16,110 &, 226 &, 212 \\
\hline $\begin{array}{l}\text { Performans } \\
\text { Değerlendirme }\end{array}$ &,- 244 &, 371 &,- 058 &,- 658 &, 511 & 16,110 &, 226 &, 212 \\
\hline Ödüllendirme &, 295 &, 338 &, 067 &, 871 &, 384 & 16,110 &, 226 &, 212 \\
\hline $\begin{array}{l}\text { Personel } \\
\text { Güçlendirme }\end{array}$ & 2,822 &, 436 &, $404^{* *}$ & 6,469 &, 000 & 16,110 &, 226 &, 212 \\
\hline
\end{tabular}

Bağımlı Değişken: İş Tatmini

$(* \mathrm{p}<0,05 * * \mathrm{p}<0,01)$

Tablo 8 incelendiğinde, performans değerlendirme, ödüllendirme ve personel güçlendirmenin iş tatmininin \% 21,2 'ini açıkladığı görülmektedir. Uygulanan regresyon analizi sonucunda eğitimin iş tatminini pozitif yönde etkilediği görülmektedir $(\beta=, 164 ; \mathrm{p}<0,05)$. Bu sonuca göre $\mathrm{H}_{1}$ hipotezi desteklenmiştir. Yapılan regresyon analizi sonucunda performans değerlendirmenin, iş tatminini pozitif yönde etkilemediği görülmektedir $(\beta=-, 058 ; \mathrm{p}>0,05)$. Bu sonuca göre $\mathrm{H}_{4}$ hipotezi desteklenmeyerek reddedilmiştir. Regresyon sonuçlarına bakıldığına, ödüllendirmenin iş tatminini pozitif yönde etki etmediği görülmektedir $(\beta=, 067 ; \mathrm{p}>0,05)$. Bu sonuca göre $\mathrm{H}_{7}$ hipotezi kabul görmeyerek reddedilmiştir. Regresyon analizi sonucu yorumlandığında personel güçlendirmenin iş tatminini pozitif yönde etkilediği görülmektedir $(\beta=, 404 ; \mathrm{p}<0,05)$. Bu sonuca göre $\mathrm{H}_{10}$ hipotezi desteklenmiştir.

Araştırmada $\mathrm{H}_{2}, \mathrm{H}_{5}, \mathrm{H}_{8}$ ve $\mathrm{H}_{11}$ " $\mathrm{H}_{2}$ : Eğitim, bireysel performans1 pozitif yönde etkiler.", " $\mathrm{H}_{5}$ : Performans değerlendirme, bireysel performansı pozitif yönde etkiler." " $\mathrm{H}_{8}$ : Ödüllendirme, bireysel performansı pozitif yönde etkiler." ve " $\mathrm{H}_{11}$ : Personel güçlendirme, bireysel performansı pozitif yönde etkiler" hipotezlerini test etmek için çoklu regresyon analizi yapılmış ve sonuçlar Tablo 9'da gösterilmiştir.

Tablo 9. İnsan Kaynakları Uygulamalarının Bireysel Performansı Etkilemesine İlişkin Regresyon Analizi ve Sonuçları

\begin{tabular}{|l|c|c|c|c|c|c|c|c|}
\hline Model & $\begin{array}{c}\text { Standartlaş } \\
\text { mamış } \\
\text { Katsayılar } \\
\mathbf{B}\end{array}$ & $\begin{array}{c}\text { Standart } \\
\text { Hata }\end{array}$ & $\begin{array}{c}\text { Standartlaş } \\
\text { mış } \\
\text { Katsayılar } \\
\text { (Beta) } \boldsymbol{\beta}\end{array}$ & $\mathbf{T}$ & $\mathbf{p}$ & $\mathbf{F}$ & $\mathbf{R}^{2}$ & $\Delta \mathbf{R}^{2}$ \\
\hline Sabit & 2,705 &, 261 & & 10,358 &, 000 & & & \\
\hline Ĕgitim &, 042 &, 057 &, 057 &, 732 &, 465 & 11,679 &, 175 &, 160 \\
\hline $\begin{array}{l}\text { Performans } \\
\text { Değerlendirme }\end{array}$ &, 018 &, 062 &, 026 &, 289 &, 773 & 11,679 &, 175 &, 160 \\
\hline
\end{tabular}




\begin{tabular}{|l|c|c|c|c|c|c|c|c|}
\hline Ödüllendirme &,- 161 &, 057 &,$- 225^{*}$ & $-2,825$ &, 005 & 11,679 &, 175 &, 160 \\
\hline $\begin{array}{l}\text { Personel } \\
\text { Güçlendirme }\end{array}$ &, 448 &, 073 &, $394^{* *}$ & 6,099 &, 000 & 11,679 &, 175 &, 160 \\
\hline
\end{tabular}

Bağımlı Değişken: Bireysel Performans

$(* \mathrm{p}<0,05 * * \mathrm{p}<0,01)$

$\mathrm{Bu}$ veriler 1şı̆̆ında Tablo 9 incelendiğinde; eğitim, performans değerlendirme, ödüllendirme ve personel güçlendirmenin, bireysel performansın \% 16'sını açıkladığı görülmektedir. Yapılan regresyon analizi sonucunda eğitimin bireysel performansı pozitif yönde etkilemediği görülmektedir $(\beta=, 057 ; \mathrm{p}>0,05)$. Bu sonuç neticesinde $\mathrm{H}_{2}$ hipotezi desteklenmeyip reddedilmiştir. Yapılan araştırmada $\mathrm{H}_{5}$ hipotez sonucuna bakacak olursak, performans değerlendirmenin bireysel performansı pozitif yönde etkilememektedir $(\beta=, 026 ; p>0,05)$. Bu sonuca göre $\mathrm{H}_{5}$ hipotezi reddedilmiştir. $\mathrm{H}_{8}$ hipotez sonucunu incelediğimizde, ödüllendirmenin bireysel performansı negatif yönde etkilediği görülmektedir $(\beta=-, 225 ; \mathrm{p}<0,05)$. Bu sonuca göre $\mathrm{H}_{8}$ hipotezi reddedilmiştir. Son olarak $\mathrm{H}_{11}$ hipotez sonucunu incelersek, personel güçlendirmenin bireysel performansı pozitif yönde etkilediği görülmektedir $(\beta=, 394 ; p<0,01) . B u$ sonuca göre $\mathrm{H}_{11}$ hipotezi desteklenmiştir.

Araştırmada $\mathrm{H}_{3}, \mathrm{H}_{6}, \mathrm{H}_{9}$ ve $\mathrm{H}_{12}$ hipotezlerini, " $\mathrm{H}_{3}$ : Eğitim, yenilikçi davranışı pozitif yönde etkiler", " $\mathrm{H}_{6}$ : Performans değerlendirme, yenilikçi davranışı pozitif yönde etkiler", " $\mathrm{H}_{9}$ : Ödüllendirme, yenilikçi davranışı pozitif yönde etkiler" ve " $\mathrm{H}_{12}$ : Personel güçlendirme yenilikçi davranışı pozitif yönde etkiler" test etmek için çoklu regresyon analizi yapılmış ve sonuçlar Tablo 10'da gösterilmiştir.

Tablo 10. İnsan Kaynakları Uygulamalarının Yenilikçi Davranışı Etkilemesine İlişkin Regresyon Analizi ve Sonuçları

\begin{tabular}{|l|c|c|c|c|c|c|c|c|}
\hline Model & $\begin{array}{c}\text { Standartlaş } \\
\text { mamış } \\
\text { Katsayılar } \\
\mathbf{B}\end{array}$ & $\begin{array}{c}\text { Standart } \\
\text { Hata }\end{array}$ & $\begin{array}{c}\text { Standartlaş } \\
\text { mış } \\
\text { Katsayılar } \\
\text { (Beta) } \boldsymbol{\beta}\end{array}$ & $\mathbf{T}$ & $\mathbf{p}$ & $\mathbf{F}$ & $\mathbf{R}^{\mathbf{2}}$ & $\Delta \mathbf{R}^{\mathbf{2}}$ \\
\hline Sabit & 1,945 &, 250 & & $, 7,772$ &, 000 & & & \\
\hline Ĕ̆itim &, 037 &, 055 &, 052 &, 676 &, 500 & 13,926 &, 201 &, 187 \\
\hline $\begin{array}{l}\text { Performans } \\
\text { Değerlendirme }\end{array}$ &,- 041 &, 060 &,- 060 &,- 679 &, 498 & 13,926 &, 201 &, 187 \\
\hline Ödüllendirme &, 015 &, 054 &, 022 &, 280 &, 780 & 13,926 &, 201 &, 187 \\
\hline $\begin{array}{l}\text { Personel } \\
\text { Güçlendirme }\end{array}$ &, 493 &, 070 &, $445^{* *}$ & 7,013 &, 000 & 13,926 &, 201 &, 187 \\
\hline
\end{tabular}

Bağımlı Değişken: Yenilikçi Davranış

$(* \mathrm{p}<0,05 * * \mathrm{p}<0,01)$

Tablo 10 incelendiğinde eğitimin, performans değerlendirme, ödüllendirme ve personel güçlendirmenin yenilikçi davranışın \% 18,7'sini açıkladığı görülmektedir. Yapılan regresyon analizi sonucunda eğitimin, yenilikçi davranışı pozitif yönde etkilemediği görülmektedir $(\beta=, 052 ; \mathrm{p}>0,05)$. Bu sonuca göre $\mathrm{H}_{3}$ hipotezi reddedilmiştir. Diğer taraftan, performans değerlendirmenin yenilikçi davranışı pozitif yönde etkilemediği görülmektedir $(\beta=-, 060 ; p>0,05)$. Bu sonuca göre $\mathrm{H}_{6}$ hipotezi reddedilmiştir. $\mathrm{H}_{9}$ hipotezi incelendiğinde ise, ödüllendirmenin yenilikçi davranışı pozitif yönde etki etmediği görülmektedir $(\beta=, 022 ; p>0,05)$. Bu sonuca göre $\mathrm{H}_{9}$ hipotezi reddedilmiştir. Son olarak, personel güçlendirmenin yenilikçi davranışı pozitif yönde etkilediği görülmektedir $(\beta=, 445 ; \mathrm{p}<0,01)$. Bu sonuca göre $\mathrm{H}_{12}$ hipotezi desteklenmiş̧ir.

\section{Sonuç}

$\mathrm{Bu}$ çalışmada, insan kaynakları yönetimi uygulamalarından; eğitim, performans değerlendirme, ödüllendirme ve personel güçlendirmenin, çalışanların; iş tatmini, yenilikçi davranışı ve bireysel performansı üzerinde etkisi olup olmadığı tespit edilmek istenmiştir. Bu çalışma kapsamında Kahramanmaraş’ta faaliyet gösteren bir kamu kurumunda çalışan bireylere anket uygulaması yapılmıştır. Araştırma neticesinde elde edilen sonuçlar aşağıda özetlenmiş ve tartışılmış̧ır.

Çalı̧̧manın birinci hipotezi $\left(\mathrm{H}_{1}\right.$ : Eğitim, iş tatminini pozitif yönde etkiler) bu çalışmada desteklenmiştir. Eğitimin iş tatminiyle pozitif ilişki içerinde olduğu korelasyon sonucunda da tespit edilmiştir. Bu sonuç, eğitimin çalışanların iş tatminine ulaşmalarında ne denli önemli bir konu olduğunu vurgularken, ilgili literatürde de eğitimin çalışanlar açısından ne denli olumlu sonuçlar doğuracağı tartışılmaktadır. Eğitim ve gelişim en yaygın insan kaynakları uygulamaları olarak kabul görmektedir (Tzafrir, 2006). Yiğit (2010) bir firma üzerinde yapmış olduğu araştırmasında 
eğitimin iş tatminini pozitif yönde etkilediğini tespit etmiş ve şu sonuçlara ulaşmıştır: Eğitim sisteminin en alt seviyeden en üst seviyeye kadar tüm çalışanların öneri ve görüşleri alınarak yapılandırıldığını tespit etmiştir. Kurumun hedefleri üst yönetimden başlayarak en alt düzeye kadar indirgenmekte ve kurum hedefleriyle çalışanların hedeflerinin gerçekleşebilmesi için gerekli olan tüm yetkinliklerin geliştirilmesi amacıyla firsat eşitliği ilkesinden hareketle tüm çalışanlar için eğitim programları hazırlanmakta ve çalışanlara zamanında uygun ortamlarda ve içerikte sunulduğunu tespit etmiştir. İşe başlayan bir personel kariyer planı doğrultusunda alacağı eğitimleri bilmektedir ve bu da çalışanların iş tatminini artırdığını belirlemiştir. Garcia (2005) çalışmasında, eğitim ve gelişimin, çalışanların iş tatmininde pozitif etkiye sahip olduğunu belirtmiştir.

Araştırmanın ikinci hipotezi $\left(\mathrm{H}_{2}\right.$ : Eğitim, bireysel performansı pozitif yönde etkiler) bu çalışmada desteklenmeyerek reddedilmiştir. Korelasyon analizi sonucunda da aralarında ilişki olmadığ 1 belirlenmiştir. Bu çalışmadaki sonucun aksine, Selimoğlu ve Yılmaz (2009) alan çalışmalarında, eğitimin çalışanların bireysel iş performansını arttırdığı sonucuna ulaşmışlardır. Çalışanların kurum içi aldıkları eğitimle kendilerini geliştirerek çalıştığı kuruma ve işine karşı motivasyonları artacağını ve çalışanların kendilerine yapılan yatırımın, onları mutlu kılıp daha verimli, daha özverili çalışarak başarılı performans göstereceklerinden bahsetmiştir.

Çalışmanın üçüncü hipotezi ( $\mathrm{H}_{3}$ : Eğitim, yenilikçi davranışı pozitif yönde etkiler) bu çalışmada reddedilmiştir. Korelasyon analizi sonucunda ise pozitif ilişki içerisinde oldukları bulunmuştur. Bazı teorik araştırmalar, yenilikçilik için personelin yetenek ve bilgi düzeyinin arttırılmasında eğitim uygulamalarının önemini araştırmıştır (Mabey ve Salaman, 1995; Schuler ve Jackson, 1987). Bazı araştırmalarda, eğitim uygulamaları ile yenilikçi davranış düzeyi arasındaki ilişki incelenmiş ve eğitim uygulamalarının yenilikçi davranışı olumlu etkilediği bulunmuştur (Mark ve Akhtar, 2003; Ding ve Akhtar, 2001). Raghuram ve Arvey (1994) gibi bazı araştırmacılar ise bunun aksi istikametinde sonuçlara ulaştıklarını belirtmişlerdir. $\mathrm{Bu}$ araştırmada ise, eğitim uygulamalarının yenilikçi davranışı olumlu etkilemediği bulunmuştur. Yukarıda yapmış olduğumuz açıklamalar ışığında da eğitimin örgütler için vazgeçilmez olduğunu belirtmiştik. Bununla ilgili daha önceki çalışmalardaki sonuçlara göre değerlendirecek olursak. Profesyonel eğitim ve gelişim programları; personelin bilgi, kabiliyet ve yetenek kazanımlarına yardım eder. Personelin mevcut iş aktivitelerini geliştirmelerini ve beslemelerini sağlar. Profesyonel bir eğitim ve gelişim sayesinde, çalışanlar daha az gözetimle daha yüksek performansa ulaşabilirler (Gutteridge vd., 1993). Sözbilir (2018) yapmış olduğu alan çalışmasında, kurum içi eğitim uygulamalarının çalışanların yenilikçi davranışını olumlu yönde etkilediği sonucuna ulaşmış ve şu önerilerde bulunmuştur: İşbaşında eğitimin boyutları olan mesleki yeterlilik, kariyer motivasyonu, eğitimci kuruluş ve eğitime ilişkin algının çalışanın öz-yeterliliğini artıran; ayrıca mesleki yeterlilik, eğitimci kuruluş, eğitime ilişkin algı ve öz-yeterliliğin çalışanın yenilikçi davranışlarını artıran faktörler olması dolayısıyla organizasyonlar söz konusu unsurlara gereken ilgi ve önemi göstermelerini belirtmiştir.

Çalışmanın dördüncü hipotezi ( $\mathrm{H}_{4}$ : Performans değerlendirme, iş tatminini pozitif yönde etkiler) bu çalışmada desteklenmiştir. Korelasyon analizi sonucunda, pozitif ilişki içerisinde oldukları sonucuna ulaşılmıştır. Yapılan literatür taraması sonucunda bazı araştırmalarda, bu çalışma sonuçlarıyla paralel olarak performans değerlendirmenin iş tatmini üzerinde olumlu etkisinin olduğu bulunmuştur. Yumuşak (2008) araştırmassında, performans değerlendirmenin iş tatmini üzerinde olumlu etkisinin olduğu sonucuna ulaşmıştır ve performans değerlemesinin çalışan memnuniyetini dikkate alması, sistemin yeterliliğine katkı sağlarken sistemden daha fazla yararlanılması sonucunu doğurduğundan bahsetmiştir. Performans değerleme sisteminde personelin düşüncelerinin dikkate alınması ve bunlara sistemde yer verilmesinin, performans değerlemenin etkinliğine olumlu katkılar sağladığı görülmektedir. Çalışanlar, düşüncelerinin ve fikirlerinin yer verildiği performans değerleme sisteminde daha adil değerlendirildiklerini düşünmektedirler.

Çalışmanın beşinci hipotezi ( $\mathrm{H}_{5}$ : Performans değerlendirme, bireysel performansı pozitif yönde etkiler) bu alan araştırmamızda, performans değerlendirmenin bireysel performansı olumlu yönde etkilemediği sonucuna ulaşılmıştır. Korelasyon analizi sonucunda da aralarında ilişki olmadığ 1 tespit edilmiştir. Performans değerlendirmenin bireysel performansa etkisiyle ilgili yapmış olduğumuz literatür araştırmasında, farklı sektörlerde yapılmış araştırmalarda performans değerlendirmenin, bireysel performansı genel olarak etkilediği sonucuna ulaşıldığı görülmektedir. Tompkins (1995) yapmış olduğu değerlendirmede, performans değerlendirme, insan kaynakları uygulamalarından en önemli uygulama araçlarından biri olduğunu ve çalışanların iş performanslarını arttırdığını belirtmiştir.

Çalışmanın altıncı hipotezi ( $\mathrm{H}_{6}$ : Performans değerlendirme, yenilikçi davranışı pozitif yönde etkiler) bu çalışmada desteklenmeyerek reddedilmiştir. Korelasyon analizi sonucunda da aralarında ilişki olmadığı sonucu elde edilmiştir. Performans değerlendirme uygulamalarının yenilikçi davranış üzerindeki etkisinin ve sonuçlarının pozitif çıkmaması, yapılan bu konudaki çalışmalarda (Erdoğmuş ve Şeneldir, 2009; Eren, 2006) bu çalışmaya benzer sonuçlara ulaşmışlardır. Eryiğit (2013) yapmış olduğu alan çalışmasında da performans değerlendirmenin yenilikçi davranışları olumlu yönde etkilemediği sonucuna ulaşmış ve performans değerlendirme sistemi kuruma uygulanırken, çalışanların bu konuda eğitim alması gerektiğini ve uygulanması kolay olan sistemler tercih edilmeli ve sistem geliştirilirken çalışanların katılımının sağlaması gerektiğinden bahsetmiştir. Korkmaz vd. (2018) KOBİ'ler üzerinde yaptıkları alan çalışmasında da bu çalışmanın aksine performans değerlendirmenin yenilikçi davranışı etkilediği sonucuna ulaşmışlardır. Çalışanı stratejide tanımlı hedefe odaklayan bir performans ölçüm sistemi geliştirmek ve buna bağlı ödüllendirmeler yapmak, inovasyon fikirlerinin artırılmasını sağlayacağından bahsetmişlerdir. Yapmış olduğumuz araştırma sonucunda, çalışanlar doğru ve hakkaniyete uygun olarak, performanslarının değerlendirildiğine inandıklarında tatmin olacaklar ve performansları üzerinde geri dönümler sağlanacak ve bu yönde yaratıcı ve yenilikçi fikirler geliştirip, bunu uygulayacakları düşünülmektedir. 
Çalışmanın yedinci hipotezi ( $\mathrm{H}_{7}$ : Ödüllendirme, iş tatminini pozitif yönde etkiler) bu çalışmada desteklenmeyerek reddedilmiştir. Korelasyon analizinde ise aralarında pozitif ilişki olduğu sonucuna ulaşılmış̧ır. Literatür incelendiğinde, bu çalışmada elde edilen sonucun aksine ödüllendirmenin iş tatminini pozitif etkilediğine dair bulgular vardır. Örneğin, Koç (2007) Garp Linyitleri işletmesindeki çalışanlara uygulanan ödül sistemlerinin iş tatmini üzerindeki etkisini ölçmek için yapmış olduğu araştırmasında, ödüllendirmenin iş tatminini etkilediği sonucunu elde etmiştir. Etkili ödül sistemi uygulayan kurumlarda, ödülün kurumsal motivasyonu etkilediği, verimliliği ve başarıyı sağlamada önemli etkilerinin olduğu ve ödül sistemlerinin çalışanların iş tatmini esas alınarak yapılması gerektiğinden bahsetmiştir. Akgün (2014) KOBI'lerde yapmış olduğu araştırmasında ise şu sonuçlara ulaşmışır. Çoğunlukla çalışanlara daha çok maddi ve sosyal imkânlar sunulduğunda motivasyonlarının daha çok sağlanıp arttığını tespit etmiştir. Bunun yanı sıra kişi hoş sözler duymak yani takdir edilmek ya da göstermiş olduğu performans karşısında terfi almak isteyebilir. Eğer kurumda çalışan kişi, bireysel hedeflerine sürekli ulaşamıyor ise çalışma ortamında gergin çalışıı̆ının anlaşılması gerektiğini ve yöneticilerin bu durumun farkına varıp bireyin motivasyonunu sağlaması gerektiğini tespit etmiştir.

Çalışmanın sekizinci hipotezi ( $\mathrm{H}_{8}$ : Ödüllendirme, bireysel performansı pozitif yönde etkiler) bu çalışmada desteklenmemiştir. Korelâsyon analizi sonucuna göre de aralarında ilişki olmadığı belirlenmiştir. Araş̧ırmamız da, ödüllendirmenin bireysel performansı negatif yönde etkilediği tespit edilmiştir. Bu çalışmada elde edilen sonucun aksine, Akçit (2011) çalışmasında, ödüllendirmenin personelin performansına olumlu etkisinin olduğu sonucuna ulaşmış ve manevi ödüllerin maddi ödüllerden daha çok personelin performansını artırdı̆̆ııı, beklenen ödül türünün genellikle manevi ödüller olduğunu tespit etmiştir. Bunun sebebinin de en çok kullanılan ödüllendirmenin "ücret artı̧̧1, prim ve ikramiye" olduğu en az kullanılan ödüllendirmenin ise "karara katılma ve görüşü alınma" olmasıdır. Diğer bir alan araştırmasında ise, Altındağ ve Akgün (2015) şu sonuçlara ulaşmışlardır: Çalışanların aldıkları ödüllerin beklentilerini karşıllaması, yaptıkları işiyle ilgili fikirlerinin sorulması, iş yapan kişilerin daha fazla sorumluluk hissine sahip olmalarını sağladığı gibi kurumun ürün veya hizmet verimliliğini de arttırdığı sonucuna ulaşmışlardır.

Çalışmanın dokuzuncu hipotezi ( $\mathrm{H}_{9}$ : Ödüllendirme, yenilikçi davranışı pozitif yönde etkiler) bu çalışmada desteklenmeyerek reddedilmiştir. Korelâsyon analizi sonucunda aralarında ilişki bulunamamıştır. Bu çalışmadaki sonucun aksine, Ekiyor ve Arslantaş (2015) yapmış oldukları çalışmada ise, ödüllendirmenin çalışanların yenilikçi davranışları üzerinde olumlu etkisinin olduğu sonucuna ulaşmışlardır. Ödüllendirilen çalışanın, yaratıcı ve yenilikçi olduklarını, aynı zamanda da memnuniyetlerinin arttı̆̆ının ortaya çıktığını ve kurumsal anlamda memnuniyet düzeylerinin yüksek olduğunu, bireysel anlamda ise memnuniyet düzeylerinin düşük olduğunu gözlemlemişlerdir. Yani, yenilikçi çalışma sırasında eğitim imkânları ve kariyer gelişimlerinin desteklenmemesi, sosyal imkânların sağlanmaması, kaynak tahsisinin (zaman, para, eğitim) yapılmaması, teşvik ve takdir edilmemesinin söz konusu olduğunu tespit etmişlerdir. Teknoloji, istenilen bilgiye ulaşım kolaylı̆̆ı, eğitim imkânları, gerekli miktarda zaman, para ve yetenekli işgücü kaynaklarının sağlanması, çalışanların yenilikçi fikirlerinin artmasını teşvik ettiğini tespit etmiştir.

Çalışmanın onuncu hipotezi $\left(\mathrm{H}_{10}\right.$ : Personel güçlendirme, iş tatminini pozitif yönde etkiler) bu çalışmada desteklenmiştir. Bu iki değişken arasında da pozitif ilişki olduğu tespit edilmiştir. Personelin kendi kararlarını alabilmesi, işiyle ilgili farklı yöntemler seçebilmesi, işini nasıl yapacağı konusunda kendisini özgür hissetmesi, alınan kararlara katılım düzeyinin sağlanması, çalışanların iş tatminini etkilediği görüşü bu çalışmada desteklenmiştir. Personel güçlendirmenin iş tatmini üzerinde pozitif etkiye sahip olduğu bulgumuz, yapılan çalışmalarla da desteklenmektedir. Kitapçı, vd. (2013) alan araştırmasında, bir bireyin işinden memnun kalması için, kendisi için anlamlı olan iş gereksinimlerine bağlı olması gerekir. İş gereksinimlerini önemli ve anlamlı olarak algılayan bireyler, çalışma potansiyellerini yansıtmaya daha isteklidir. Yaptı̆̆ işin hem kendisi için hem de görev yaptı̆̆ kurumu için anlamlı olduğuna inanan birey, yaptı̆̆ işine karşı pozitif tutumlar sergilemekte ve daha fazla memnun olmaktadır. Kamuda çalışan bir birey için, çalış̧ı̆̆ bölümde gerçekleşen olaylar üzerinde etkisi olduğuna inanması, iş tatminini arttırır. Kendini bölümde gerçekleşen olaylar üzerinde etkisiz hisseden birey ise, devamlı tedirgin olmakta ve iş memnuniyetsizliği yaşamaktadır. Karavardar (2017)'in yaptığı alan çalışması da elde edilen sonuçları destekler niteliktedir.

Çalışmanın on birinci hipotezi $\left(\mathrm{H}_{11}\right.$ : Personel güçlendirme, bireysel performansı pozitif yönde etkiler) bu çalışmada desteklenmiştir. Yapılan korelasyon analizi de, personel güçlendirmeyle bireysel performans arasında pozitif ilişki olduğunu göstermektedir. Yaptığı işin kendisi için önemli olduğunu düşünen, yaptığı işin kendisi için anlam taşıdığını düşünen, yapacağı işi nasıl yapacağı konusunda kendini özgür hisseden, bölümünde alınan kararlara katılımı sağlanan çalışan, motive olup performansı artmakta ve yaptığı işle ilgili verimliliği artmaktadır. Bektaş ve Karagöz (2018) yaptıkları araştırmada, personel güçlendirmenin bireysel performansı pozitif etkilediği sonucunu elde etmişlerdir. Bu araştırmanın bu yönüyle paralellik gösterdiği görülmektedir. Ekiyor ve Karagul (2016) çalışmalarında da personel güçlendirmenin bireysel performansı pozitif yönde etkilediği sonucuna ulaşmışlar ve bu çalışmada elde sonuçla da paralellik göstermektedir. Personel güçlendirme; çalışanların istekli olmasını, performansını ve kuruma olan güvenini artırarak, çalışanlara önemli fayda sağlamaktadır. Çalışanların fikirlerinin aşağıdan yukarıya gitmesine yardımcı olacak, güçlendirici bir örgüt kültürü oluştururken, kurum liderleri kişisel yönetim tarzlarının doğruluğunu ve etkinliğini dürüst bir şekilde değerlendirmelidir. Yöneticiler, çalışanların sesini dinlemekten çok daha fazlasını yapmalıdır. Çalışanların sadece fikirlerini beyan etmelerine için değil, aynı zamanda çalışanların uygulamaya katılmalarını teşvik etmelidirler (Doğan, 2006). 
Çalışmanın on ikinci hipotezi ( $\mathrm{H}_{12}$ : Personel güçlendirme, yenilikçi davranışı pozitif yönde etkiler) bu çalışmada desteklenmiştir. Korelasyon analizi sonucunda da pozitif ilişki içerisinde oldukları sonucuna ulaşılmıştır. Kurumunda yaptı̆̆ işle ilgili güçlendirilen ve bunu hisseden çalışanın daha yenilikçi olduğunu söyleyebiliriz. Bu durum çalışanın yaptığı işi anlamlı bulması ve kendisini bu işte yetenekli görmesi, çalışanın kendisini daha yenilikçi hissetmesini sağladığını göstermektedir. Benzer şekilde işiyle ilgili kararları bağımsız bir şekilde alan çalışanın, kendisini daha yenilikçi hissettiği söylenebilir. Orta ve alt düzey çalışan özerklik kazandıkça yani, bağımsız kararlar alabildikçe ve bu kararları uygulama özgürlüğüne kavuştukça, yenilikçi davranış düzeyi de artmaktadır. Yaptığımız araştırmalarda Çavuş (2006) çalışmasında bunu destekler niteliktedir. Kerse ve Karabey (2014) çalışmasında da personel güçlendirmenin, çalışanların yenilikçi davranışlarına pozitif etkisi olduğunu tespit etmiştir. Benzer şekilde çalışanların işlerinde özgür olması ve işlerini etkilemesi, işlerini anlamlı bulması ve yeteneklerine güvenmesi, yani çalışanların güçlendirilmesi yenilikçilik yeteneklerini artırmakta, diğer bir ifadeyle yeni ve farklı fikirler ile hizmet sunmaya katkıda bulunmaktadırlar.

$\mathrm{Bu}$ çalışma 1şı̆̆ında şu önerilergeliştirilmiştir: Yöneticiler, kurumda etkin bir eğitim sistemi kurmalı ve çalışanların iş gelişiminin sağlanması için, belirli aralıklarla çalışanlara eğitim programları uygulanmalıdır. Çalışanlara yönelik performans değerlendirme adil olmalı ve performans değerlendirme yılda bir veya iki defa yerine, yılın belirli bölümlerinde sistematik bir şekilde yapılmalıdır. Kurumda adil bir ödüllendirme sistemi kurulmalıdır. $\mathrm{Bu}$ ödüllendirmeler, maddi (pirim, ikramiye vb.) ve manevi (takdir, terfi vb.)olarak çalışanlara uygulanmalıdır. Kurumda çalışanlara görevleriyle ilgili bir takım yetkiler verilmeli, çalışanların her konuda üst yönetime danışmak yerine üstünlük almaları sağlanmalıdır. Bu, çalışanın verimliliğini arttıracak, işinden tatmin olmasını sağlayacak ve işiyle ilgili yeni fikirler ve düşünceler geliştirmesine imkan sunacaktır. Ayrıca yöneticiler, çalışanların iş tatminini, bireysel iş performansını ve yenilikçi iş davranışını arttırıcı şartları kurumda oluşturmalı ve bu yöndeki politikaları, çalışanlara uygulamaları gerektiğini söyleyebiliriz.

Her çalışmada olduğu gibi bu çalışmanın da bir takım kısıtları vardır. İlk olarak, araştırmada kullanılan örneklem Kahramanmaraş’ta bir kamu kuruluşunda görev yapan çalışanları kapsamaktadır. Diğer bir sınırlama ise çalışmanın sadece Kahramanmaraş ilinde yapılmasıdır. Bu çalışma, birden fazla kamu kuruluşu ile farklı illerde ve bölgelerde ele alınabilir. Ayrıca çalışmaya, iş tatminini, yenilikçi davranışı ve bireysel performansı etkiyen farklı değişkenlerde eklenebilir. Yukarıdaki sınırlamalara rağmen, bu çalışmanın ilgili literatürlere katkı sağlayacağını ve ileride yapılacak çalışmalara 1şık tutacağını düşünmekteyiz. Elde edilen sonuçların kamu çalışanlarının iş tatmininin, yenilikçi davranışının ve bireysel performans artışının sağlanması açısından önem taşımaktadır. $\mathrm{Bu}$ sonuçlar kamu kurumlarındaki karar vericilere, dikkate almaları için önemli bilgiler sunmuştur. 


\section{KAYNAKÇA}

Akal, Z., (2005). İşletmelerde Performans Ölçüm ve Denetimi-Çok Yönlü Performans Göstergeleri, Prodüktivite Merkezi Yayınları, No: 473, Ankara.

Akçakanat, T. (2009). İnsan kaynakları Yönetiminde Performans Değerlendirme: Isparta İllat Müdürlüğü’nde Bir Uygulama, Yüksek Lisans Tezi, Süleyman $\quad$ Demirel Üniversitesi Sosyal Bilimler Enstitüsü, Isparta.

Akçit, V. (2011). Örgütlerde Ödüllendirme ve Cezalandırmanın Örgüt Çalışanlarının Performansına $\quad$ Etkisi, Yüksek Lisans Tezi, Pamukkale Üniversitesi SBE İşletme Anabilim Dalı, Denizli.

Akgün, B. (2014). Örgütlerde Ödüllendirmenin İş Gören Motivasyonu ve Performansı Üzerindeki Etkisi Üzerine Ampirik Bir Çalışma, Yüksek Lisans Tezi, Beykent Üniversitesi SBE. İşletme Yönetimi Anabilim Dali, İstanbul.

Aktaş, R. (2002). Toplam Kalite Yönetimi İle Uyumlu İnsan Kaynakları Yönetim ～Süreçleri, $\quad$ Verimlilik Dergisi, Milli Prodüktivite Merkezi Yayınları, YayınNo:2002/1, ss.40-57.

Altındağ, E. ve Akgün, B. (2015). Örgütlerde Ödüllendirmenin İşgören Motivasyonu ve Performansı Üzerindeki Etkisi, Mustafa Kemal Üniversitesi Sosyal Bilimler Enstitüsü Dergisi, 12(30), ss.281-297.

Aşan, Ö. ve Aydın, E.M.(2006). Örgütsel Davranış, Ed.: Halil Can, Arıkan Basım Yayım Dağıtım

LTD. ŞTİ., İstanbul, 469s.

Barker, A. (2001). Yenilikçiliğin Simyası, (Çev. A. Kardam), MESS Yayınları, Yayın No:391.

Basım, H.N. ve Şeşen, H. (2009). Örgütsel Adalet Algısı-Örgütsel Vatandaşlık Davranışı İlişkisinde İş Tatmininin Aracılık Rolü, 17. Yönetim ve Organizasyon Kongresi Bildiriler Kitabı, Eskişehir, 21-23 Mayıs.

Baş, İ.M. ve Artar, A. (1990). İşletmelerde Verimlilik Denetimi-Ölçme Denetleme ～Modelleri, MPM Yayınları, Ankara.

Bektaş, M. ve Karagöz, Ş. (2018). Algılanan Güçlendirmenin Çalışanların Performans ve Örgütsel Vatandaşlık Davranışları Üzerine Etkisi, Sosyal Araştırmalar ve Davranış Bilimleri Dergisi, 4(5), ss.31-46.

Bingöl, D. (2013). İnsan Kaynakları Yönetimi, Beta Yayıncılık, İstanbul, 722s.

Blake, B.F., Neuendorf, K.A. ve Valdiserri, C.E. (2003). Inovative Bhavior Variety of Internet Shopping, Internet Resarch: Electronic Networking and Applications andPolicy, 13(3), pp.156-169.

Boddy D.(2002). Management An Introduction, Second Edition, Prentice Hall, England.

Bowen, E.D. ve Lawler, E. (1992). The Empowerment of Service Workers: What, Why, How and When, Sloan Management Review, 33, pp.31-39.

Canman, D. (1995). Çağdaş Personel Yönetimi, TODAİE Yayını No:260, Ankara.

Chin-Ju T. (2006). High Performance Work Systems And Organizational Performance: An Emprical Study of Taiwan's Semiconduductor Desing Firms, The International Journal of Human Resource Management, 17, pp.1512-1530.

Czinkota, M.R., Ronkainen, I.A., Moffet, M.H. ve Moynihan, E.O.(1998). Global Business, The Dryden Press, United states of America.

Çalık, T.(2003). Performans Yönetimi-Tanımlar, Kavramlar, İlkeler, Gündüz Eğitim ve Yayıncılık, Ankara, 118s.

Çavuş, M. F.(2006). İşletmelerde Personel Güçlendirme Uygulamalarının Örgütsel Yaratıcılık ve Yenilikçiliğe Etkileri Üzerine İmalat Sanayinde Bir Uygulama, Doktora Tezi, Selçuk Üniversitesi SBE. İşletme Anabilim Dalı, Konya, 220s.

Çetin, F. ve Basım, H.N.(2011). Psikolojik Dayanıklılığın İş Tatmini ve Örgütsel Bağlılık Tutumlarındaki Rolü, "İşGüç”" Endüstri İlişskileri ve İnsan Kaynakları ～Dergisi, 13(3), ss.79-94.

Çiftyıldız, K.(2015). İnsan Kaynakları Bilgi Sistemlerinin İş Tatmini ve Örgütsel Bağlılığa $\quad$ Etkisi: $\quad$ Doğu Marmara ISO 500 Firma Örneği, Doktora Tezi, Sakarya Üniversitesi SBE. Sakarya, 169s.

Çöl, G. (2008). Algılanan Güçlendirmenin İşgören Performansı Üzerine Etkileri, Doğuş Üniversitesi Dergisi， 9(1), ss.35-46.

Çuhadar, M. T.(2005). Türk Kamu Kesiminde Personel Güçlendirme: Sorunlar ve ～Çözüm Önerileri, Erciyes Üniversitesi İİBF Dergisi, 25, ss.2-25.

De Cenzo, D. A. ve Robbins, S. P. (1996). Human Resource Management, John Wiley and Sons, New York, States of America, 620p.

De Jong, J. ve Den Hartog, D. (2010). Measuring Innovative Work Behaviour, Creativity and Innovation Management, 19(1), pp.23-36.

Deeprose, D. (1994). How to Recognize and Reward Employes, AMACOM American Management Association, New York.

Ding, D.Z. ve Akhtar, S. (2001). The organizational choice of human resource management practices: A study of Chinese enterprises in three cities in the PRC. International Journal of Human Resource Management, 12,pp.946-964.

Doğan, S. (2006). Personel Güçlendirme, Kare Yayınları 2. Baskı, İstanbul.

Ehtiyar, V.R. (1996). Otel İşletmelerinde Çalışan Personelin İş Tatmini ve Antalya ～Yöresinde yapılan Bir Araştırma, Verimlilik Dergisi, ss.109-121. 
Ekiyor, A ve Karagul, S. (2016). Sağlık Sektöründe Personel Güçlendirmenin İşgören Performansına $\quad$ ve $\quad$ İç Girişimciliğe Etkisi, Uluslararası Sağlık Yönetimi veStratejileri Dergisi, 1(3), ss.2149-6161.

Ekiyor, A. ve Arslantaş, S. (2015).Sağlık Sektöründe İşgören Motivasyonunun İnovasyon Performansına Etkileri, Çankırı Karatekin Üniversitesi Sosyal Bilimler Enstitüsü Dergisi, 6(2), ss.113-136.

Erdoğan, İ. (1999). İşletme Yönetiminde Örgütsel Davranış, Dönence Basın Yayın, İ́stanbul.

Erdoğmuş, N. ve Şeneldir, O. (2009). Bireysel Performans Yönetim Sisteminin Kurulmasında

Karşılaşılan Sorunlarına Yönelik Kocaeli Bölgesi Sanayi İşletmelerinde Nitel Bir Araştırma,17. Ulusal Yönetim ve Organizasyon Kongresi Bildiriler Kitabı, Osman Gazi Üniversitesi Yayınları No:162, $\quad$ Eskişehir.

Eren, M. (2011). İnsan Kaynakları Yönetimi, Beta Yayıncılık, İstanbul, 330s.

Eren, V. (2006). Personel Rejiminde Bürokratik Modelden İşletmeci Anlayışa Geçiş, Selçuk Üni. Sosyal ve Ekonomik Araştırmalar Dergisi, 6(11), ss.131-153.

Eryiğit, N. (2013). İnsan Kaynakları Yönetimi Uygulamalarının Yenilik Performansına Etkisi, Doktora Tezi, Karadeniz Teknik Üni. Sosyal Bilimler Enstitüsü, Trabzon.

Fındıkçı, İ.(2000). İnsan Kaynakları Yönetimi, 2. Baskı, Alfa Basım, İstanbul, 412s.

Fındıkçı, İ.(2012). İnsan Kaynakları Yönetimi, Alfa Yayıncılık, İstanbul, 510s.

G a r c a , M. (2005). Training and Business Performance: The Spanish Case. International Journal of Human Resource Management, 16, pp.1691-1710.

Genç, N. (2004). Yönetim ve Organizasyon: Çağdaş Sistemler ve Yaklaşımlar, Seçim Yayınevi, Ankara, 424s.

Guest, E., Michie, J., Conway, N. ve Sheehan, M. (2003). Human Resource Management And Corporate Performance İn the UK, British Journal of Industrial Relations, 41(2), pp.291-314.

Gutteridge, T.G., Leibowitz, Z.B. ve Shore, J.E. (1993). Organizational Career Development, Jossey-Bass, San Francisco, CA.

Güney, S.(2014). İnsan Kaynakları Yönetimi, Nobel Yayınları, Ankara, 274s.

Hackman, R. ve Oldham, G.R. (1975). Development of the Jop Diagnostic Survey, Journal of Applied Psychology, 60(2), pp.159-170.

Hayajneh, A.Y. (2000). Identification of The Influence of Orgaziational Variables On Haspital Staff NursesJop Performance, Doctorate Dissertation, University of Lowa, USA.

Haznedar, B.(2006). İnsan Kaynakları Yönetimi Uygulamalarının Firma Performansına Etkileri, Yüksek Lisans Tezi, Gebze Yüksek Teknoloji Enstitüsü, İşletme ABD, Gebze.

Jamrog, J., Vikkers, M., ve Bear, D. (2006). Buildingand Sustaining a Culture That Supports Innovation, Human Resources Planning, Academic Journal Article

Jong, J. P. J. ve Hartog, D. N. (2008). Innovative WorkBehavior Measurementand Validation, http://www.ondernemerschap.nl/pdfez/H200820.pdf (Erişim Tarihi,10.09.2018).

Jorge, T. ve Teece, D. (1992). Innovation, CooperationandAntitrust, Oxford University Press, New York.

Karatepe, S. (2005). Ödüllendirme Yönetimi: Örgütlerde Güdülemeye Duyarlı Bir ～Yaklaşım, ～Ankara Üniversitesi SBF Dergisi, 60(4), ss.117-132.

Karavardar, G. (2017). Mavi Yakalı Çalışanlarda Psikolojik Personel Güçlendirme ve İş Tatmini Arasındaki İlişkileri Belirlemeye Yönelik Görgül Bir Araştırma, Osmaniye Korkut Ata Üni. İİF Dergisi, 1(1),ss.15-26.

Kaya, N. ve Kesen, M. (2014).İnsan Kaynakları Yönetimi Uygulamaları ve Örgüt Kültürü Tiplerinin Çalışan Performansı Üzerindeki Etlilerini İncelemeye YönelikAmpirik Bir Çalışma, Akev Akademi Dergisi, 58(58), ss.97-122.

Kerse, G. ve Karabey, C.N. (2014). Personel Güçlendirme ile Bireyin Yaratıcılık Algısı Arasındaki İlişki: Bankacılık Sektöründe Bir Uygulama, Akdeniz Üni., İ̈BF Dergisi, 14(29), ss.22-41.

Khanka, S. S.(2007). Human Resource Management, S. Chand \& Company LTD., $\quad$ New Delhi, 217s.

Kırım, A. (2007). Süreç İnovasyonu: Maliyetleri Sistem Dışına Çıkarmak, sistem Yayıncılık, İstanbul.

Kitapçı, H., Kaynak, R. ve Ökten, S.S.(2013). Güçlendirmenin İş Tatmini ve İşten Ayrılma Niyetine Etkisi: Kamu ve Özel Sektörde Mukayeseli Bir Araştırma, International Review of Economics and Management, $1(1)$, ss.49-73.

Koç, A. (2007). Örgütlerde Ödüllendirme Sistemlerinin İş Tatmini ile İlişkisine Yönelik Bir $\quad$ Araştırma, Yüksek Lisans Tezi, Dumlupınar Üni. SBE. İşletme Anabilim Dalı, Kütahya.

Koçel, T. (2005). İşletme Yöneticiliği, Beta Yayım Dağıtım A.Ş., İstanbul, 569s.

Korkmaz, İ.H., Taşkesen, A.C. ve Çetinkaya, C. (2018). İnovasyon Yönetimi Süreçlerini Etkileyen Faktörlerin Kahramanmaraş’taFaaliyet Gösteren Kobiler Üzerinden İncelenmesi, Research Studies Anatolia Journal, 1(2), ss.113-125.

Kör, B. (2015). Öz Liderlik, Örgütlerin Girişimcilik Yönelimi ve Çalışanların Yenilikçi İş Davranışları Arasındaki İlişkinin İncelenmesi: Bir Araştırma, Doktora tezi, İstanbul Üniversitesi Sosyal Bilimler Enstitüsü İşletme Anabilim Dalı, İstanbul, 405s.

Kuzutürk, B. (2016). İnsan Kaynakları Yönetimi Uygulamalarının Örgütsel Performansa Etkisi, Yüksek Lisans Tezi, Başkent Üniversitesi Sosyal Bilimler Enstitüsü, Ankara.

Lawler, E. (2000). Rewarding Excellence, Jossey-Bass Publishers, Colifornia.

Leap, T.L. ve Crino, M.D. (1993). Personnel Human Resource Management, MacmillanPublishing Company, Printed in the United States of America, 719p. 
Mabey, C., ve Salaman, G. (1995). Strategic Human Resource Management: A Reader. Oxford: Blackwell.

Mark, S.K.M. ve Akhtar S. (2003). Human resources management practices, strategic orientations, and company performance: a correlation study of publicly listed companies, Journal of American Academy.

Miner, J. B.(1994). Congruence and fit in Professional Role Motivation Theory, Organization Science, 5(1), ss.1-13.

Naktiyok, A. (2007). Yenilik Yönetimi ve Örgütsel Faktörler, Atatürk Üniversitesi 21(2), ss.211-230.

Özer, K.O, Ergün, Ö. ve Okatan, T. (2015). Personel Güçlendirmenin İşTatmini Otelcilik Sektörü Araştırması, Kastamonu Üniversitesi İIBF Dergisi, 6, 104-115.

Özpehlivan, M.(2015). Kültürel Farklılıkların İşletmelerde Örgüt İçi İletişim, İş $\quad$ Tatmini,Bireysel Performans ve Örgütsel Bağlılık Kavramları Arasındaki İlişkiye Etkileri:Türkiye-Rusya Doktora Tezi, Okan Üniversitesi SBE. İşletme ABD, İstanbul, 365s.

Peçen, Ü. (2012). İnsan Kaynakları Yönetimi Uygulamaları ve Organizasyonel İklimin Firma Yenilikçilik Düzeyi Üzerine Etkileri: ABD Firmaları ve Türk Firmaları Karşılaştırması， Doktora Tezi， Gebze Yüksek Teknoloji Enstitüsü, SBE, Gebze.

Pekdemir, I., Koçoğlu, M. ve Gürkan, G.Ç. (2014). Özerklik ve Ödüllendirme Algılarının Çalışan Performansı Üzerindeki Etkisinde Çalışanın İnovasyona Yönelik Davranışının Aracılık Rolüne Yönelik Bir Araştırma, İstanbul Üniversitesi İşletme Fakültesi Dergisi, 43(2), ss.332-350.

Pitts, C. (1995). Motivating Your Organization, Achieving Business Success Through Reward and Recognition, McGraw-Hill Book Company, England.

Price, J.L. ve Mueller, C.W. (1981). A Casual Model of Turnoverfor Nurses, The Academyof Management Journal, 24(3), pp.543-565.

Raghuram, S. ve Arvey, R. (1994). Business Strategy Links with Staffing and Training Practices, Human Resources Planning, 17(3),pp.55-73.

Sabuncuoğlu, Z. (1994). Personel Yönetimi, Politika ve Yönetsel Teknikler, Rota Ofset, Bursa.

Schuler, R. ve Jackson, S. (1987). Linking Competitive Strategies and Human Resource Management Practices, Academy of Management Executive, 1(3), pp.207-219.

Selimoğlu, E. ve Yılmaz, H.B.(2009).Hizmet İçi Eğitimin Kurum ve Çalışanlar Üzerine Etkileri, Ekonomi, Sosyoloji ve Politika Dergisi, 5(1), ss.1-12.

Sevimli, F. ve İşcan, Ö.F. (2005). Bireysel ve İş Ortamına Ait Etkenler Açısından İşs Tatmini, $\quad$ Ege $\quad$ Akademik Bakış, 5(1-2), ss.55-64.

Sigler,T.H. ve Pearson, C. M. (2000). Creating An Empowering Culture: Examining The RelationshipBetween Organizational Culture and Perceptions Ofempowerment. Journalof QualityManagement, 5(1), pp.2752.

Sökmen, A. (2014). İşletmelerde Yönetim ve Organizasyon, Detay Yayıncılık, Ankara, 489s.

Sözbilir, F. (2018). İşbaşı Eğitim Uygulamaları, Öz-Yeterlilik Ve Yenilikçilik DavranışıArasındaki İlişki, İşletme Araştırmaları Dergisi, 10(1), ss.119-142.

Spreitzer, G.M. (1995). Psychological empowerment in the workplace: dimensions, measurement, and validation. Academy of Management Journal, 38(5), pp.1442 1465.

Tompkins, J. (1995). Human Resource Management in Government: Hitting the Ground ～Running, Harper Collins College Publishers, New York.

Tortop, N., Aykaç, B., Özer, M. ve Yayman, H.(2013). İnsan Kaynakları Yönetimi, ～Nobel Akademik Yayincilik, Ankara, 584s.

Tutum, C. (1979). Personel Yönetimi, Türkiye ve Ortadoğu Amme İdaresi Enstitüsü $\quad$ Yayınları, Ankara.

Türk, S.M. (2007). Örgüt Kültürü ve İş Tatmini (1. Bask1), Özkan Matbaacılık, Ankara.

T z a f r i r, S.S. (2006). A universalistic perspective for explaining the relationship between HRM practices and firm performance atdifferent points in time.Journal of Managerial Psychology, 21(2), pp.109-130.

Usta, A.(2010). Kamu Kurumlarında Örgütsel Performans Yönetim Süreci, Sayıştay Dergisi, 78, ss.34-37.

Uyargil, C. (2015). İnsan kaynakları Yönetimi İ.Ü. İşletme Fakültesi İnsan Kaynakları Yönetimi Anabilim Dalı, Beta Yayıncilık, İstanbul, 700s.

Yeşil, S. (2014). İnsan Kaynağının Eğitimi ve Gelişimi”, İnsan Kaynakları Yönetimi， Ed.: İsmail Bakan, Gazi Kitabevi, Ankara, ss.191-235.

Yetiş, Ş.A. ve Katlav, E.Ö. (2017). Turizm Eğitimi Veren Akademisyenlerinin İş $\quad$ Tatmin ve Performans Düzeylerinin Bireysel Özelliklerine Göre Değişmesi, $\quad$ Verimlilik Dergisi 1, ss.7-27.

Yıldırım, B. (2015). Stratejik İnsan Kaynakları Yönetiminin Kurumsal Performansa Etkisi: İstanbul Üniversitesi'nde Bir Uygulama, Yüksek Lisans Tezi, İstanbulGelişim Üniversitesi, SBE, İşletme ABD, İstanbul.

Yıldırım, C. (2008). İlköğretim Okulu Öğretmen ve Yöneticilerinin Öğretmenlerin ～Ödüllendirilmesi İlişkin Görüşleri, Kuram ve Uygulamada Eğitim Yönetimi, 56, ss.663-690.

Yılmaz, T.(2012). Yüksek Performanslı İnsan Kaynakları Yönetimi Uygulamalarının Bireysel ve Örgütsel Performansa Etkisi, Yüksek $\quad$ Lisans Tezi, Kara Harp Okulu Komutanlığı, Savunma Bilimleri Enstitüsü, Savunma Yönetimi Anabilim Dalı, $\quad 177 \mathrm{~s}$. 
Yiğit, B. (2010). (İnsana Yatııım Standardı) Çerçevesinde Uygulanan İnsan Kaynakları Sisteminin Çalışanların İş Tatminine Etkisi, Yüksek Lisans Tezi, Marmara Üniversitesi, SBE, Çalışma Ekonomisi ve Endüstri İlişkileri ABD, İstanbul.

Yoon, M.H. ve Suh, J. (2003). Organizational Citizenship Behaviors and Service Quality As External Effectiveness Of contact Employes, Journal of Business Research, 56(8), ss.597-611.

Yumuşak, S. (2008).Performans Değerlemesinin Etkinliğine Etki Eden Faktörlerin Tespitine Yönelik Alan Araştırması, Yönetim ve Ekonomi Araştırmaları Dergisi, $\quad 6(10)$ ss.44-62. 